Ertürk, R. \& Akgün, N. (2021). Öğretmenlerin davranışsal güçlendirilmesi ile örgütsel adanmışlıkları arasındaki ilişki. Bolu Abant İzet Baysal Üniversitesi Eğitim Fakültesi Dergisi, 21(4), 1212-1229. https://dx.doi.org/10.17240/aibuefd.2021..998170

Makalenin Türü / Article Type Geliş Tarihi / Date Received Kabul Tarihi / Date Accepted Yayın Tarihi / Date Published
: Araştirma Makalesi / Researh Article

: 15.12 .2021

https://dx.doi.org/10.17240/aibuefd.2021..-998170

\title{
ÖĞRETMENLERİN DAVRANIŞSAL GÜÇLENDİRİLMESİ İLE ÖRGÜTSEL ADANMIŞLIKLARI ARASINDAKİ İLIŞKİ*
}

\author{
Ramazan ERTÜRK ${ }^{1}$, Nuri AKGÜN ${ }^{2}$
}

ÖZ

$\mathrm{Bu}$ araştırmanın amacı, öğretmenlerin davranışsal güçlendirilmesi ile örgütsel adanmışlık algılarını belirlemek ve bunlar arasında anlamlı bir ilişki olup olmadığını ortaya koymaktır. Araştırma, ilişkisel tarama modelinde tasarlanmıştır. Araştırmanın çalışma evrenini Bolu ili merkez ilçede bulunan resmi ilkokul, ortaokul ve liselerde 2020-2021 eğitim-öğretim yılında görev yapan öğretmenler oluşturmuştur. Araştırmada veri toplama aracı olarak "Kişisel Bilgi Formu", "Öğretmenlerin Davranışsal Açıdan Güçlendirilmesi Ölçeği" ve "Öğretmenlerin Örgütsel Adanmışlık Ölçeği" kullanılmıştır. Araştırma sonuçlarına göre, öğretmenlerin davranışsal güçlendirilme algıları ölçek genelinde ve boyutlarında "çoğu zaman" düzeyinde; örgütsel adanmışlık algıları, ölçek genelinde ve boyutlarında "yüksek" düzeydedir. Davranışsal güçlendirme ölçeği ve boyutları ile örgütsel adanmışlık ölçeği ve boyutları arasında pozitif yönlü anlamlı ilişki vardır.

Anahtar Kelimeler: Öğretmen, davranışsal güçlendirme, örgütsel adanmışlık

\section{THE RELATIONSHIP BETWEEN TEACHERS' BEHAVIORAL EMPOWERMENT AND ORGANIZATIONAL COMMITMENT}

\begin{abstract}
The aim of this study is to determine teachers' perceptions of behavioral empowerment and organizational commitment in terms of different variables and to reveal whether any meaningful relationships between them. The study was designed in the relational survey model. The population of the study consists of teachers working in official primary, secondary, and high schools in the central district of Bolu in the 2020-2021 academic year. The "Personal Information Form", "Behavioral Empowerment of Teachers Scale", and "Teachers' Organizational Commitment Scale" were used as data collection tools in the study. The results showed that the behavioral empowerment perceptions of teachers were at the level of "almost every time" and the organizational commitment perceptions were at a "high" level across the scale and in its dimensions. Teachers' perceptions of behavioral empowerment displayed meaningful significance across the scale, in the dimensions of delegation of authority, participation in decision, and teamwork, based on the educational status variable. There were significant positive correlations between the behavioral empowerment scale and its dimensions and the organizational commitment scale and its dimensions.
\end{abstract}

Keywords: Teacher, behavioral empowerment, organizational commitment

\footnotetext{
* Bu araștırma Dr. Öğretim Üyesi Nuri AKGÜN'ün danışmanlı̆ğnda Dr. Ramazan ERTÜRK tarafindan hazırlanan Doktora tezinin bir bölümünden üretilmiştir.

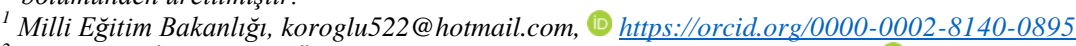

2 Bolu Abant İzzet Baysal Üniversitesi, Eğitim Fakültesi, akgun_n@ibu.edu.tr, (1) https://orcid.org/0000-0003-3225-6193
} 


\section{GíRiş}

İnsanoğlu var oluşundan bu yana ihtiyaçlarını karşılamak için çaba göstermiştir. Ancak her ihtiyacını tek başına karşılayamadığı için örgütler kurmuş ve bu örgütlerin varlığını sürdürebilmesi için yine kendisi çalışmıştır. Giderek artan rekabet ortamında bu ihtiyaçların karşılanması, örgütlerin kaliteli ürün ve hizmet üretmesi ve amaçlarına ulaşmasıyla mümkün olacaktır. Örgütlerin kaliteli ürün ve hizmet üreterek amaçlarını gerçekleştirebilmeleri, gerekli nitelikleri olan kaliteli, etkili ve verimli çalışan, yeterli sayıda insan kaynağına sahip olmaları, sahip oldukları insan kaynağının ihtiyaçlarını karşılayarak örgütte kalmasını ve işbirliği içinde çalı̧̧masını sağlamasıyla mümkündür (Barnard, 1982). Dolayısıyla çalışanların görevlerini etkili ve verimli bir şekilde yerine getirebilmelerinde örgütün hedef ve amaçlarıyla bütünleşerek yapması gerekenden daha fazla rol üstlenmeleri oldukça önemlidir. Çalışanların bu şekilde davranmaları onların örgütsel adanmışlıklarıyla yakından ilişkilidir. Örgütlerde adanmışlı̆ıın ön plana çıkması, insan faktörünün öneminin artırılmasıyla mümkün olmaktadır. Çalışanın örgütteki gereksinim ve beklentileri karşılandığı zaman örgütsel adanmışlığı artmaktadır (Güçlü, 2006).

Adanmışlık, pozitif duygular içinde işe odaklanmak, işe kendini vererek gayret göstermek, üst seviyede bir enerji ile işe bağlılık duymaktır (Caymaz vd., 2013). Bireylerin uyumlu ve üretken olmaları, doyuma ulaşmaları, yüksek düzeyde sorumluluk ve sadakat içinde çalı̧̧maları, örgütteki maliyetin azalması bireylerin örgütsel adanmışlığı ile mümkündür. Örgütsel adanmışlık, örgütlerin varlıklarını sürdürme çabalarının ana etkinliklerinden ve hedeflerindendir (Balcı, 2003). Örgütsel adanmışlık, çalışanların örgütün hedeflerine ulaşması için gösterdiği çaba ve örgüte sadakat (Karasoy, 2011), çalışanların örgüt amaç ve değerlerine inancının yüksek olması ve bunları kabul ederek bu amaçlara ulaşmak için çaba sarfetme isteğinin olması, örgütte kalarak bunu sürdürülebilir hâle getirmek için duydukları güçlü bir arzudur (Boylu vd., 2007).

Eğitim örgütlerinin en önemlilerinden biri olan okulların amaçlarına ulaşmasında eğitimin temel öğeleri olarak kabul edilen öğretmenlerin önemli rolleri vardır. Bu anlamda okulların amaçlarına ulaşmasında, eğitim öğretim faaliyetlerinin etkili ve verimli bir şekilde yürütülmesinde, sağlıklı bir okul iklimi ve kültürünün oluşturulmasında öğretmenlerin örgütsel adanmışlıklarının önemli olduğu düşünülmektedir.

Öğretmenlerin örgütsel adanmışlığını Celep (2000); okula adanma, öğretim işlerine adanma, öğretmenlik mesleğine adanma, çalışma grubuna adanma olarak çok boyutlu ele almıştır. Okula adanma, öğretmenlerin güçlü bir şekilde inandıkları okulun amaçlarını kabul edip okula adanmışlklarını, okulları için fazladan çaba gösterme istekleri ve okuldaki görevlerini sürdürme arzularıdır (Randall, 1987). Öğretim işlerine adanma, her öğretmen ve okul yöneticisinin işi ile ilgili etkinliklere kendini adamaya ilişkin kişisel olarak harcadığı zaman miktarı; çalş̧ma grubuna adanma öğretmenlerin okuldaki diğer öğretmenlerle özdeşleşmesi ve onlara bağll1ık duygusudur (Celep, 2000). Öğretmenlik mesleğine adanma, öğretmenin belli bir alanda beceri ve uzmanlık kazanmak amacı ile yaptığı çalışmalar neticesinde mesleğinin yaşamındaki önemini ve merkeziliğini algılamasıdır (Baysal \& Paksoy, 1999).

Örgütlerin istedikleri verimlilik düzeyine ulaşmaları ve hedeflerini gerçekleştirmelerinde kilit unsurlardan biri olan çalışanların adanmışlıkları performans, yaratıcılık ve yenilikçilik becerilerinin arttırılmasına katkı sağlamaktadır. Örgütler adanmış katalizör çalışanları sayesinde başarı elde ederek hedeflerine ulaşabilmekte, küresel rekabette üstünlüğünü sürdürülebilir hale getirmektedir (Yavan, 2016). Eğitim örgütlerinin en önemlisi olan okullarda ise, ögretmenlerin performans, yaratıcılık ve yenilikçilik becerilerinin artırılarak okulun başarıya ulaştrılmasında ve rekabet üstünlüğü kazanmasında etkili olan yönetim tarzı, görevin anlamlılı̆̆ı, özerklik, karara katılma, takım çalışması, geri bildirim, işbirliği, öğrenme firsatları, ücret ve kaynak gibi faktörler örgütsel adanmışlık algısının belirleyici unsurlarıdır (Bozdemir, 2012). Bu faktörler örgütsel adanmış̧ı̆̆ın belirleyicileri olmalarının yanı sıra öğretmenleri güçlendirmede önemli yer tutmaktadır. Dolayısıyla örgütsel adanmışlğ̆ın belirleyicileri olan bu faktörlerin öğretmenlerin davranışsal açıdan güçlendirilmesiyle ilişkili olduğu düşünüldüğünde, öğretmenlerin örgütsel adanmışlıklarının geliştirilmesinde davranışsal olarak güçlendirilmelerinin etkili bir faktör olduğu söylenebilir.

Yönetim literatürü ve uygulamalarında güçlendirme kavramına yönelik ilgi yüksek düzeydedir. Çünkü güçlendirme yönetsel ve örgütsel etkililiği sağlamanın temel bileşenlerinden biridir. Nitekim örgüt ve yönetim uygulamalarında yöneticilerin güç ve kontrolü çalışanlarıyla paylaşımı örgütlerin üretkenliğini ve verimini sağlamaktadır (Conger \& Kanungo, 1988). Güçlendirme, çalışanların işlerini yaparken inisiyatif kullanmaları, karar verme süreçlerine katılabilme ve etkili performans gösterebilmeleri için yöneticilerin çalışanlarına yetki ve sorumluluk devretmesidir (Bedük, 2012). Çalışanların güçlendirilmesi kavramı, yardımlaşma, paylaşma ve takım çalışması ile çalışanların karar verme yetkilerini arttıran ve gelişmelerini sağlayan psikolojik ve davranışsal boyutu olan bir süreç olarak tanımlanabilmektedir (Koçel, 2005). Psikolojik güçlendirme çalışanın deneyimlediği güçlenmenin algısal veya psikolojik boyutlarına odaklanmaktadır (Dewettinck \& Van Ameijde, 2011). Spreitzer (1995) psikolojik güçlendirmeyi anlamlılık, yetkinlik, özerklik ve etki olmak üzere dört boyutta ele almıştır. Davranışsal güçlendirme, yetki ve kontrol dağıtımı, güç paylaşımı, çalışanlara özerklik sağlama, 
yönetici sorumluluklarının çalışanlar tarafından adil bir şekilde paylaşılması (Hales \& Klidas, 1998; Klagge, 1998), çalışanlara desteğin en yüksek seviyede olması (Appelbaum vd., 1999), çalışanların katılımının sağlandığı karar verme süreci, örgüt vizyonunun ve amaçlarının takım çalışmalarıyla belirlenmesi ve paylaşılması, gelişim ve motivasyon için yetki ve sorumluluğun tam olarak anlaşılması sağlanarak örgütsel amaçlar doğrultusunda orantılı olarak kullanılmasıdır (Herrenkohl vd., 1999). Kıral (2015) çalışmasında öğretmenlerin davranışsal açıdan güçlendirilmesini yetki devri, yönetsel destek, karara katılma, takım çalışması ve iletişim olarak ele almıştır. $\mathrm{Bu}$ araştırmada da ögretmenlerin davranışsal güçlendirilmesi bu boyutlar dikkate alınarak değerlendirilmiştir.

Yetki devri, yöneticinin karar verme ve bu kararı uygulama hakkını çalışanlara devretmesi ve onların kullanmasını sağlamasıdır (Koçel vd., 1991). Yönetsel destek, örgüt içi çalışmalar sonucunda çalışanın algıladığı yönetimin verdiği destektir (Eisenberger vd., 1990). Karara katılım, bireylerin grup amaçlarına katkıda bulunmasını sağlayan bir süreçtir (Şahin, 2017). Takım çalışması, öğretmenlerin sorunları çözmek için birlikte çalışmaları, sorumlulukları paylaşmaları, yeni beceriler öğrenmeleridir (Dee vd., 2002). Bireylerin etrafindakiler üzerinde etkili olmasını sağlayan toplumsal bir olgu olan iletişim, bireyler ve gruplar arasında paylaşımı sağlamaktadır (Zillığlu, 1996).

Güçlendirilmiş çalışanlar daha yüksek iş memnuniyetine, üretkenlik ve yenilikçilik davranışlarına sahiptirler. Ürettikleri ürünler ve verdikleri hizmetler yüksek kalitededir. Böylelikle güçlendirilmiş iş gücüne sahip örgütler daha etkili olmaktadırlar (Whetton \& Cameron, 2011). Okul örgütlerinde de okul yöneticileri öğretmenlerin gelişimlerini etkileyen önemli bir unsurdur. Herkes için sağlıklı ve pozitif bir öğrenme ortamı oluşturarak bunu sürdürmek, öğretmen gelişimini sağlamak okul yöneticilerinin öncelikli görevidir (Bredeson \& Johansson, 2006). Okullarda eğitim-öğretim faaliyetlerinin verimliliğe ulaşması, uygulamacı konumunda olan öğretmenlerin güçlendirilmesiyle mümkündür. Kendisi, öğrencileri ve okulu için fayda sağlayan güçlendirilmiş öğretmenler iş ve yaşamlarında belli bir amaç doğrultusunda hareket ederek katılımcı bir anlayışla doğrudan iş ortamlarının ve sistemlerinin iyileşmesini sürekli hale getirirler (Özdaşl1, 2002). Ayrıca öğretmenlerin güçlendirilmesinde önemli bir yeri olan yetki devri, yönetim desteği, karara katılım, işbirliği ve takım çalışmaları ile iletişim boyutları örgütsel adanmışlığın öncüllerini oluşturmaktadır. Bundan dolayı öğretmenlerin güçlendirilmesi, örgütsel adanmışlıkları açısından oldukça önem taşımaktadır.

Literatürde "öğretmenlerin davranışsal açıdan güçlendirilmesi" konulu çalışmaların (Kıral, 2015; Ökmen, 2018; Taş, 2017) azlığı dikkat çekmektedir. Örgütsel adanmışlığın farklı değişkenlerle ilişkisinin araştırıldığı çalışmalar bulunmasına rağmen öğretmenlerin davranışsal açıdan güçlendirilmesi ile örgütsel adanmışlıkları arasındaki ilişkinin belirlenmesi yönetim literatüründe eksik kalmış bir konudur.

\subsection{Araştırmanın amacı}

$\mathrm{Bu}$ araştırmanın amacı, öğretmenlerin davranışsal güçlendirilmesi ile örgütsel adanmışlık algı düzeylerine ilişkin görüşlerini farklı değişkenlere göre tespit ederek bunlar arasında anlamlı bir ilişkinin olup olmadığını ortaya koymaktır. $\mathrm{Bu}$ amacı gerçekleştirmek için aşağıdaki sorulara cevap aranacaktır:

1- Öğretmenlerin davranışsal güçlendirilme ve örgütsel adanmışlık algıları ne düzeydedir?

2- Öğretmenlerin davranışsal güçlendirilmesi ile örgütsel adanmışlık algıları arasında anlamlı bir ilişki var midir?

\subsection{Araştırmanın önemi}

Öğretmenler, öğrenci başarısı ve okuluın etkililiğinde en önemli değişkenlerdendir. Bu durum, eğitim öğretim faaliyetlerinin etkili olması ve dolayısıyla öğrenci ve okulun başarıya ulaşmasında öğretmenlerin davranışsal açıdan güçlendirilmesini gerekli kılmaktadır. Öğretmenlerin güçlendirilmesinde ise en önemli görev okul yöneticilerine düşmektedir. Okul yöneticilerinin öğretmenlere yetkilerini devretmesi ve destek sağlaması, karar almada onların görüşlerini alması, etkili iletişim kurarak takım çalışmalarını desteklemesi öğretmenlerin davranışsal olarak güçlenmelerini sağlamaktadır. Okulların etkililik ve verimliliğinde önemli bir yeri olduğu düşünülen öğretmenlerin örgütsel adanmışlı düzeylerinin yükseltilmesinde öğretmenlerin davranışsal olarak güçlendirilmesinin önemi büyüktür. Çünkü öğretmenlere verilen yetki, gerekli olan örgütsel ve yönetsel destek ile öğretmenlerin karara katılımlarının sağlanması, okulda takım çalışmalarına önem verilmesi ve sağlıkı bir iletişim ağının kurulması onları güçlendirecektir. Bu anlamda öğretmenlerin davranışsal güçlendirilmesi ile örgütsel adanmışlıkları arasındaki ilişkinin tespit edilmesi, hem yönetim literatürüne sağlayacağı katkı hem de eğitim yönetimi ve denetimi alanında kurumların ve yöneticilerin öğretmenlerin güçlendirilmesi ve örgütsel adanmışlık durumlarını değerlendirmesi açısından önemlidir. 


\section{YÖNTEM}

\subsection{Araştırmanın modeli}

Nicel araştırma desenlerinden ilişkisel tarama modelinde tasarlanan araştırma betimsel bir çalışmadır. Tarama modeli geçmişte ve var olan durumu olduğu gibi betimleyemeyi amaçlamakta iken, ilişkisel tarama modeli iki ya da daha çok değişken arasında birlikte değişim varlığını ve/veya derecesini belirlemeyi amaçlamaktadır (Karasar, 2005).

\subsection{Araştırmanın çalışma evreni}

Araştırmanın ulaşılabilir evren olarak çalışma evrenini, 2020-2021 eğitim-öğretim yılı birinci döneminde Bolu ili merkez ilçedeki resmî ilkokul, ortaokul ve liselerde (genel, mesleki ve teknik) görev yapan 2157 öğretmen oluşturmuştur. Araştırmada çalışma evreninin tamamına ulaşılmak hedeflendiğinden örneklem almak yoluna başvurulmamıştır. İlkokullarda 362, ortaokullarda 264 ve liselerde 290 öğretmen olmak üzere toplam 916 öğretmenden ölçeklere ilişkin dönüt sağlanmıştır.

\subsection{Veri toplama araçları}

Araştırma verilerini toplamak için Kıral (2015) tarafından geliştirilen "Öğretmenlerin Davranışsal Açıdan Güçlendirilmesi Ölçeği" ile Celep (2000) tarafindan geliştirilen "Öğretmenlerin Örgütsel Adanmışlık Ölçeği" kullanılmıştır.

\subsection{1. Öğretmenlerin Davranışsal Açıdan Güçlendirilmesi Ölçeği}

Kıral (2015) tarafından geliştirilen ölçek, beş boyuttan oluşmaktadır. Ölçekte yetki devri boyutunda 5, yönetsel destek boyutunda 4, karara katılım boyutunda 9, takım çalışması boyutunda 8 ve iletişim boyutunda 4 madde olmak üzere toplam 30 madde bulunmaktadır. Ölçek 5'li Likert tarzında olup "hiçbir zaman" (1), "nadiren" (2), "ara sıra" (3), "çoğu zaman" (4) ve "her zaman" (5) olarak derecelendirilmektedir. Ölçeğin değerlendirilmesinde "hiçbir zaman" 1.00-1.79, "nadiren" 1.80-2.59, "ara sıra" 2.60-3.39, "çoğu zaman" 3.40-4.19, "her zaman" 4.205.00 sınır değerleri kullanılmıştır.

Kıral (2015) tarafından ölçeğin tamamının ve boyutların güvenilirliğini belirlemek amacıyla hesaplanan Cronbach alfa güvenilirlik katsayıları yetki devri ve yönetsel destek için .87, karara katılım için .96, takım çalışması için .97 ve iletişim için .90 olarak saptanmıştır. Ölçeğin tümü için ise iç tutarlık katsayısı .98 olarak hesaplanmıştır. Bu araştırmada Cronbach alfa güvenilirlik katsayıları ölçeğin tümü için .98, yetki devri için .87, yönetsel destek için .85, karara katılım için .97, takım çalışması için .98 ve iletişim boyutu için .91 olarak saptanmıştır. Ölçeklerin güvenilirliğinin göstergesi olarak ölçek bütünü ve alt boyutları için hesaplanan iç tutarlılık katsayılarının yüksek düzeyde olması ölçeklerin güvenilir olduğunu göstermektedir (Ural \& Kılıç, 2005). Dolayısıyla bu araştırmada tespit edilen Cronbach alfa güvenirlik katsayıları Öğretmenlerin Davranışsal Güçlendirilmesi Ölçeği ile boyutlarının güvenilirlik düzeylerinin yüksek olduğunu göstermektedir.

\subsection{2. Örgütsel Adanmışlık Ölçeği}

Celep (2000) tarafından geliştirilen dört boyutlu Eğitim Örgütlerinde Öğretmenlerin Örgütsel Adanmışlık Ölçeği, okula adanma boyutu 9, öğretim işlerine adanma boyutu 7, öğretmenlik mesleğine adanma boyutu 6 ve çalışma grubuna adanma boyutu 6 madde olmak üzere 28 maddeden oluşmaktadır. Okula adanma boyutundaki 13. ve 25. maddeler ters kodlanmıştır. Beşli Likert tipinde hazırlanan ölçek "çok az" (1), "az" (2), "ara sıra" (3), "çoğu zaman" (4) ve "her zaman" (5) şeklinde derecelendirilmektedir. Araştırmada Örgütsel Adanmışlık Ölçeği ve boyutlarının aritmetik ortalamalar1 1.00-1.79 "çok düşük", 1.80-2.59 "düşük", 2.60-3.39 "orta", 3.40-4.19 "yüksek", 4.20-5.00 aralığı ise "çok yüksek" şeklinde yorumlanmıştır.

Celep (2000), öğretmenlerin örgütsel adanmışlık ölçeğindeki maddelerin bütününün güvenilirliği için hesaplanan Cronbach alfa katsayısını .88 olarak belirlemiştir. Cronbach alfa katsayısı boyutlardan okula adanma için .80, öğretim işlerine adanma için .75, öğretmenlik mesleğinde adanma için .78, çalışma grubuna adanma için ise .81 olarak saptanmıştır. $\mathrm{Bu}$ araştırmada yapılan Cronbach alfa analizi sonucunda güvenilirlik katsayısı ölçeğin toplamında .90 , okula adanma boyutunda .73 , öğretim işlerine adanma boyutunda .77 , öğretmenlik mesleğine adanma boyutunda .82 , çalışma grubuna adanma boyutunda .88 olarak hesaplanmıştır. Buna göre Cronbach alfa ( $\alpha$ ) güvenirlik katsayısı sonuçları örgütsel adanmışlık ölçeği geneli ile okula adanma, öğretmenlik mesleğine adanma ve çalışma grubuna adanma boyutlarının güvenirliğinin yüksek olduğunu; öğretim işlerine adanma boyutunun ise oldukça güvenilir olduğunu göstermektedir. 


\subsection{Veri toplama süreci}

Araştırma verilerinin toplanabilmesi için ölçeklerin kullanım izinleri araştırmacılardan yazılı olarak alınmıştır. Ölçeklerin uygulanması için Bolu Valiliğinden gerekli izinler alınmıştır. Araştırma verilerinin toplanması çevrim içi (online) olarak gerçekleştirilmiştir. Bu kapsamda araştırma bağlantısı çalışma evreninde yer alan ve Bolu ili merkez ilçede bulunan 25 resmi ilkokul, 24 resmi ortaokul ve 19 resmi lisede (genel, mesleki ve teknik) görevli 2157 öğretmene resmi yazı aracıllığıla duyurulmuştur.

"Öğretmenlerin "Öğretmenlerin Davranışsal Açıdan Güçlendirilmesi" ile "Örgütsel Adanmışlık" ölçeklerinin araştırmanın çalışma evreninde yer alan öğretmenlere online olarak ulaştırılması ve uygulanması için okul yönetimleriyle yüz yüze ve telefonla yapılan görüşmelerde gerekli bilgilendirmeler yapılmıştır. Bu görüşmelerde Bolu Valiliği ve Bolu Abant İzzet Baysal Üniversitesi Sosyal Bilimlerde İnsan Araştırmaları Etik Kurulundan alınan izinler ibraz edilerek destek istenmiştir. Katılımda gönüllülüğün esas alındığ 1 süreçte öğretmenlerin ölçekleri yanıtlamaları için 12 Ekim-10 Kasım 2020 tarihleri arasında okul müdürlüklerine telefon ve e-posta aracılığıyla ulaşılarak hatırlatma yapılmıştır.

\subsection{Verilerin analizi}

Araştırmada elde edilen verilere hangi testlerin uygulanacağını belirlemek amacıyla veri dağılımının normalliği Kolmogorov-Smirnov ve Shapiro-Wilk testleri ile çarpıklık-basıklık (Skewness-Kurtosis) katsayıları aracıllğıyla incelenmiştir (Büyüköztürk, 2011; Kilmen, 2015; Tabachnick \& Fidell, 2013). Kolmogorov-Smirnov ve Shapiro-Wilk testleri $(\mathrm{p}<0.05)$ ile çarpıklık-basıklık katsayılarına göre, ölçek ve boyutlarına ait toplam puanlarda verilerin normal dağılmadığı tespit edilmiştir. Ölçekler ve boyutlarına ait çarpıklık-basıklık katsayılarının +5.850 ve -6.901 arasında değiştiği saptanmıştır. Çarpıklık-basıklık katsayılarının +1.5 ve -1.5 arasında olmaması verilerin normal dağılım göstermediği anlamına gelmektedir (Tabachnick \& Fidell, 2013). Dolayısıyla araştırmada parametrik olmayan testler kullanılmıştır.

\subsection{Araştırmanın etik izni}

Yapılan bu çalışmada "Yükseköğretim Kurumları Bilimsel Araştırma ve Yayın Etiği Yönergesi" kapsamında uyulması gerektiği belirtilen tüm kurallara uyulmuştur. Yönergenin ikinci bölümü olan "Bilimsel Araştırma ve Yayın Etiğine Aykırı Eylemler" başlığı altında belirtilen eylemlerden hiçbiri gerçekleştirilmemiştir.

\section{Etik kurul izin bilgileri}

Etik değerlendirmeyi yapan kurul adı: Bolu Abant İzzet Baysal Üniversitesi Sosyal Bilimlerde İnsan Araştırmaları Etik Kurulu

Etik değerlendirme kararının tarihi: 26.05.2020

Etik değerlendirme belgesi sayı ve numarası: 2020/104

\section{BULGULAR}

Bu bölümde öğretmenlerin davranışsal güçlendirilme ve örgütsel adanmışlık algıları ile davranışsal güçlendirme ile örgütsel adanmışlıkları arasındaki ilişkilere yönelik bulgular, bu bulgulara yönelik değerlendirmeler ve yorumlar yer almaktadır.

\section{1. Öğretmenlerin davranışsal güçlendirilme algıları}

Öğretmenlerin davranışsal güçlendirilme algılarına ait aritmetik ortalama ve standart sapma değerleri Tablo 1'de verilmiştir.

\section{Tablo 1.}

Öğretmenlerin Davranışsal Güçlendirilme Algılarına Ait Aritmetik Ortalama ve Standart Sapma Değerleri

\begin{tabular}{llcc}
\hline Ölçek ve boyutları & $\mathbf{N}$ & $\overline{\mathbf{x}}$ & $\mathbf{S S}$ \\
\hline Yetki devri & 916 & 3.87 & 0.75 \\
Yönetsel destek & 916 & 4.16 & 0.74 \\
Karara katılım & 916 & 4.00 & 0.86 \\
Takım çalışması & 916 & 4.17 & 0.89 \\
İletişim & 916 & 3.67 & 0.97 \\
Davranışsal güçlendirme & 916 & 4.00 & 0.78 \\
\hline Not. 1.00-1.79 "Hiçbir zaman", 1.80-2.59 "Nadiren", 2.60-3.39."Ara sıra". 3.40-4.19 "Çŏgu zaman" 4.20-5.00 "Her zaman".
\end{tabular}

Not. 1.00-1.79 "Hiçbir zaman", 1.80-2.59 "Nadiren", 2.60-3.39."Ara sıra", 3.40-4.19 "Coğu zaman" 4.20-5.00 "Her zaman".

Tablo 1 incelendiğinde öğretmenlerin davranışsal güçlendirmeye yönelik görüşlerinin davranışsal güçlendirme ölçeği toplam puan ortalaması $(\bar{x}=4.00)$ ile yetki devri boyutu $(\bar{x}=3.87)$, yönetsel destek boyutu $(\bar{x}=4.16)$, karara 
katılım boyutu ( $\bar{x}=4.00)$, takım çalışması boyutu ( $\bar{x}=4.17)$ ve iletişim boyutunda ( $\bar{x}=3.67)$ "çoğu zaman" düzeyinde olduğu görülmektedir. Ölçek toplam puan ortalaması ve boyutlar bakımından öğretmenler davranışsal açıdan "çoğu zaman" düzeyinde güçlendirildiklerini ifade etmişlerdir. Öğretmenler, kendilerini ve öğretim işlerini doğrudan ilgilendiren yönetsel destek ve takım çalışması boyutlarında daha yüksek düzeyde güçlendirildiklerini daha çok, yönetsel eylemler ve yönetime katılma ile ilişkili olan yetki devri ve karara katılım ile iletişim boyutlarında ise daha düşük düzeyde güçlendirildiklerini belirtmişlerdir.

\section{2. Öğretmenlerin örgütsel adanmışlık algıları}

Öğretmenlerin örgütsel adanmışlık algılarına ait aritmetik ortalama ve standart sapma değerleri Tablo 2'de verilmiştir.

Tablo 2.

Öğretmenlerin Örgütsel Adanmışlık Algllarına Ait Aritmetik Ortalama ve Standart Sapma Değerleri

\begin{tabular}{lccc}
\hline Ölçek ve boyutları & $\mathbf{N}$ & $\overline{\mathrm{x}}$ & $\mathbf{S S}$ \\
\hline Okula adanma & 916 & 3.76 & 0.70 \\
Öğretim işlerine adanma & 916 & 4.18 & 0.49 \\
Öğretmenlik mesleğine adanma & 916 & 4.11 & 0.67 \\
Çalışma grubuna adanma & 916 & 3.58 & 0.77 \\
Örgütsel adanmışlık & 916 & 3.90 & 0.52 \\
\hline
\end{tabular}

Not. 1.00-1.79 "çok düşük", 1.80-2.59 "düşük", 2.60-3.39 "orta", 3.40-4.19 "yüksek", 4.20-5.00 "çok yü̈ksek".

Tablo 2 incelendiğinde öğretmenlerin örgütsel adanmışlık algılarının örgütsel adanmışlık ölçeği toplam puan ortalaması ( $\bar{x}=3.90)$ ile okula adanma boyutu $(\bar{x}=3.76)$, öğretim işlerine adanma boyutu $(\bar{x}=4.18)$, öğretmenlik mesleğine adanma boyutu ( $\bar{x}=4.11)$ ve çalsşma grubuna adanma boyutunda $(\bar{x}=3.58)$ "yüksek" düzeyde olduğu tespit edilmiştir. Aritmetik ortalamalara göre alt boyutlar kendi içinde değerlendirildiğinde öğretmenlerin örgütsel adanmışlık algılarının en fazla, öğretim işlerine adanma ve öğretmenlik mesleğine adanma boyutlarında, daha sonra okula adanma ve çalışma grubuna adanma boyutlarında olduğu görülmektedir. Bu durum, öğretmenlerin bir meslek olarak öğretmenlik ile okuldaki öğretmenlik kavramlarını farklı algıladıkları şeklinde açıklanabilir.

\section{3. Öğretmenlerin davranışsal güçlendirilmesi ile örgütsel adanmışlık algıları arasındaki ilişkilere yönelik bulgular}

Öğretmenlerin davranışsal güçlendirilmesi ile örgütsel adanmışlık algıları arasındaki ilişkilerin tespit edilmesine yönelik Spearman sıra farkları korelâsyon katsayısı sonuçlarına Tablo 3 'te yer verilmiştir.

\section{Tablo 3.}

Ögretmenlerin Davranışsal Güçlendirilmesi ile Örgütsel Adanmışlık Algıları Arasındaki Ilişkilere Yönelik Spearman Sıra Farkları Korelâsyon Katsayısı Sonuçları

\begin{tabular}{lllllll}
\hline Davranışsal güçlendirme ölçeği ve boyutları & \multicolumn{6}{c}{ Örgütsel adanmışlı ölçeği ve boyutları } \\
\hline Yetki devri & & OA & ÖIA & ÖMA & ÇGA & ÖA \\
Yönetsel destek & $\mathrm{r}$ & $.464^{* *}$ & $.288^{* *}$ & $.230^{* *}$ & $.222^{* *}$ & $.391^{* *}$ \\
Karara katılım & $\mathrm{r}$ & $.520^{* *}$ & $.287^{* *}$ & $.216^{* *}$ & $.264^{* *}$ & $.422^{* *}$ \\
Takım çalışması & $\mathrm{r}$ & $.534^{* *}$ & $.279^{* *}$ & $.225^{* *}$ & $.262^{* *}$ & $.430^{* *}$ \\
İletişim & $\mathrm{r}$ & $.540^{* *}$ & $.275^{* *}$ & $.236^{* *}$ & $.278^{* *}$ & $.439^{* *}$ \\
Davranışsal güçlendirme & $\mathrm{r}$ & $.550^{* *}$ & $.284^{* *}$ & $.238^{* *}$ & $.333^{* *}$ & $.463^{* *}$ \\
& $\mathrm{r}$ & $.582^{* *}$ & $.315^{* *}$ & $.259^{* *}$ & $.317^{* *}$ & $.480^{* *}$
\end{tabular}

**p<0.01 Not. OA: Okula adanma; ÖİA: Öğretim işlerine adanma; ÖMA: Öğretmenlik mesleğine adanma; ÇGA: Çalışma grubuna adanma; ÖA: Örgütsel adanmışlı./Mutlak değer korelasyon katsayısı: 0.71-1.00 yüksek; 0.70-0.31 orta; 0.30-0.00 düşük düzeyde bir ilişkiyi işaret etmektedir (Büyüköztürk, 2011).

Tablo 3'e göre davranışsal güçlendirme ölçeği ile örgütsel adanmışlık ölçeği toplam puanları arasında orta düzeyde pozitif yönlü anlamlı bir ilişki $(r=.480 ; p<0.01)$ olduğu tespit edilmiştir. Bu iki değişken arasındaki pozitif yönlü ve orta düzeydeki ilişkinin varlığı, öğretmenlerin davranışsal güçlendirilme algılarının yükselmesiyle birlikte örgütsel adanmışlık algılarının da aynı yönde değişim gösterdiği anlamına gelmektedir. Bir başka ifadeyle, öğretmenlerin davranışsal güçlendirilme algıları yükseldikçe örgütsel adanmışlık düzeylerinin de yükseldiği söylenebilir. Ölçeklerin boyutları arasındaki ilişkilere yönelik yapılan analiz sonuçları aşağıda verilmiştir.

Davranışsal güçlendirme ölçeğinin yetki devri boyutunda; örgütsel adanmışlık ölçeğinin okula adanma (r=.464; $\mathrm{p}<0.01)$ boyutu ve ölçek genelinde $(\mathrm{r}=.391 ; \mathrm{p}<0.01)$ pozitif yönlü ve orta düzeyde anlamlı bir ilişsi; örgütsel adamışlık ölçeğinin öğretim işlerine adanma ( $r=.288 ; \mathrm{p}<0.01)$, öğretmenlik mesleğine adanma $(r=.230 ; p<0.01)$ ve çalışma grubuna adanma $(r=.222 ; \mathrm{p}<0.01)$ boyutları arasında pozitif yönlü, düşük düzeyde anlamlı bir ilişki 
saptanmıştır. Bu bulgular, yetki devri ile öğretmenlerin örgütsel adanmışlık boyutları ve ölçeğin bütünü arasında anlamlı ilişkilerin olduğunu ortaya koymaktadır.

Davranışsal güçlendirme ölçeğinin yönetsel destek boyutunda; örgütsel adanmışlık ölçeğinin okula adanma $(\mathrm{r}=.520 ; \mathrm{p}<0.01)$ boyutu ile örgütsel adanmışlı ölçeğinin bütünü arasında $(\mathrm{r}=.422 ; \mathrm{p}<0.01)$ pozitif yönlü ve orta düzeyde anlamlı ilişkiler; örgütsel adanmışlık ölçeğinin öğretim işlerine adanma $(r=.287 ; p<0.01)$, öğretmenlik mesleğine adanma $(r=.216 ; \mathrm{p}<0.01)$ ve çalışma grubuna adanma $(\mathrm{r}=.264 ; \mathrm{p}<0.01)$ boyutları arasında pozitif yönlü ve düşük düzeyde anlamlı ilişkiler saptanmıştır. Okul yöneticilerinin öğretmenlere bilgi ve yeteneklerini kullanma firsatı vermelerinin, sınıf ve okula ait fiziki ihtiyaçlarını karşılamalarının öğretmenlerin adanmışlıklarında önemli bir yeri olduğu düşünülmektedir.

Davranışsal güçlendirme ölçeğinin karara katılım boyutunda; örgütsel adanmışlık ölçeğinin okula adanma $(\mathrm{r}=.534 ; \mathrm{p}<0.01)$ boyutu ile örgütsel adanmışlık ölçeği genelinde $(\mathrm{r}=.430 ; \mathrm{p}<0.01)$ pozitif yönlü ve orta düzeyde anlamlı ilişkiler; örgütsel adamışlık ölçeğinin öğretim işlerine adanma ( $(=.279 ; \mathrm{p}<0.01)$, öğretmenlik mesleğine adanma $(\mathrm{r}=.225 ; \mathrm{p}<0.01)$ ve çalışma grubuna adanma $(\mathrm{r}=.262 ; \mathrm{p}<0.01)$ boyutları arasında pozitif yönlü ve düşük düzeyde anlamlı ilişkiler saptanmıştır. Bu bulgular, öğretmenlerin örgütsel adanmışlıklarının sağlanmasında karara katılımlarının önemli olduğunu göstermektedir.

Davranışsal güçlendirme ölçeğinin takım çalışması boyutunda; örgütsel adanmışlık ölçeğinin okula adanma $(\mathrm{r}=.540 ; \mathrm{p}<0.01)$ boyutu ile örgütsel adanmışlık ölçeği genelinde $(\mathrm{r}=.439 ; \mathrm{p}<0.01)$ pozitif yönlü ve orta düzeyde anlamlı ilişkiler; örgütsel adamışlık ölçeğinin öğretim işlerine adanma $(r=.275 ; p<0.01)$, öğretmenlik mesleğine adanma $(\mathrm{r}=.236 ; \mathrm{p}<0.01)$ ve çalışma grubuna adanma $(\mathrm{r}=.278 ; \mathrm{p}<0.01)$ boyutları arasında pozitif yönlü ve düşük düzeyde anlamlı ilişkiler saptanmıştır.

Davranışsal güçlendirme ölçeğinin iletişim boyutunda; örgütsel adanmışlık ölçeğinin okula adanma ( $\mathrm{r}=.550$; $\mathrm{p}<0.01)$ ve çalışma grubuna adanma $(\mathrm{r}=.333 ; \mathrm{p}<0.01)$ boyutları ile örgütsel adanmışlık ölçeği genelinde $(\mathrm{r}=.463$; $\mathrm{p}<0.01)$ pozitif yönlü ve orta düzeyde anlamlı ilişkiler; örgütsel adanmışlık ölçeğinin öğretim işlerine adanma $(\mathrm{r}=.284 ; \mathrm{p}<0.01)$ ve öğretmenlik mesleğine adanma $(\mathrm{r}=.238 ; \mathrm{p}<0.01)$ boyutları arasında pozitif yönlü ve düşük düzeyde anlamlı ilişkiler saptanmıştır.

Davranışsal güçlendirme ölçeği genelinde; örgütsel adanmışlık ölçeğinin okula adanma ( $r=.582 ; \mathrm{p}<0.01)$, öğretim işlerine adanma $(\mathrm{r}=.315 ; \mathrm{p}<0.01)$ ve çalışma grubuna adanma $(\mathrm{r}=.317 ; \mathrm{p}<0.01)$ boyutları ile örgütsel adanmışlık ölçeği genelinde $(\mathrm{r}=.480 ; \mathrm{p}<0.01)$ pozitif yönlü ve orta düzeyde anlamlı ilişkiler; örgütsel adanmışlık ölçeğinin öğretmenlik mesleğine adanma $(\mathrm{r}=.259 ; \mathrm{p}<0.01)$ boyutu arasında pozitif yönlü ve düşük düzeyde anlamlı bir ilişki tespit edilmiştir. Güçlendirmenin öğretmenlere çalışma özerkliği, problem çözme becerisi, öz güven, yönetici desteği, karara katılım, inisiyatif ve sorumluluk alabilme, güven ve iş birliği içerisinde çalışma firsatı, karşılıklı iletişim ve etkileşim sağladığı göz önünde bulundurulduğunda, öğretmenlerin davranışsal güçlendirilmesi ile örgütsel adanmışlık ve alt boyutları arasındaki pozitif yönlü ilişkilerin varlığı, öğretmenlerin okul vizyonunu benimsemelerini, çalı̧̧ma isteklerinin ve amaçlara ulaşma çabalarının, eğitim öğretim faaliyetlerinde performans ve verimliliklerinin artmasını ve dolayısıyla öğrenci ve okul başarısının yükselmesini, öğretmenlerin mesleğe yönelik düşüncelerinin olumlu olmasını, meslekleriyle gurur duymalarını, meslektaşlarıyla beraber olmaktan ve birlikte çalışmaktan zevk almalarını sağlayacaktır. Sonuç olarak öğretmenlerin davranışsal güçlendirilmesi ile örgütsel adanmışlıkları arasındaki pozitif yönlü ilişkinin varlığı, okul yöneticileri tarafından güçlendirilen öğretmenlerin adanmışlı düzeylerinin de aynı yönde hareket ederek yükseleceği şeklinde yorumlanabilir.

\section{TARTIŞMA ve SONUÇ}

$\mathrm{Bu}$ bölümde, araştırmanın sonuçları doğrultusunda yapılan tartışmalara ve genel sonuca yer verilmiştir.

\section{1. Öğretmenlerin davranışsal güçlendirilme algılarına yönelik tartışma ve sonuç}

Öğretmenlerin davranışsal güçlendirilmeye yönelik algıları; ölçek geneli ile yetki devri, yönetsel destek, karara katılım, takım çalışması ve iletişim boyutlarının tamamında "çoğu zaman" düzeyindedir. Öğretmen algılarına göre okul yöneticileri, öğretmenlerin kendilerini doğrudan ilgilendiren konularda (takım çalışması, yönetsel destek) daha etkin bir güçlendirme yapmakta iken öğretmenleri dolaylı yönden ilgilendiren ve yönetsel ağırlıklı konularda daha düşük düzeyde bir güçlendirme yapmaktadır. Kıral (2015) çalışmasında öğretmenlerin yönetsel destek ve takım çalışması boyutlarında en yüksek düzeyde güçlendirildikleri, daha sonra yetki devri ve karara katılım boyutlarının geldiği ve en düşük iletişim boyutunda güçlendirildikleri sonucuna ulaşmıştır. Belirtilen araştırmada ulaşılan sonuçlar bu araştırmanın sonuçlarını destekler niteliktedir.

Öğretmenlerin yetkilendirilmesi, iş doyumu, yenilikler için sunulan firsatlar, mesleki gelişim, karara katılım, okul yönetiminin çatışmalarla baş edebilme gücü, eşit iş dağılımı, ortak vizyon oluş̧urma, sağlıklı iletişim, yönetim desteği öğretmen adanmışlığını etkileyen olumlu faktörlerdir (Celep, 2014). Adanmışlığı etkileyen 
faktörler göz ününde bulundurulduğunda belirtilen faktörlerin birçoğu öğretmenlerin güçlendirilmesi ile ilgili olduğundan okul yöneticilerinin öğretmenleri yetki devri, yönetsel destek, karara katılım, takım çalışması ve iletişim boyutları ile ölçek genelinde güçlendirmeleri öğretmenlerin adanmışlık düzeylerinin yükselmesini sağlayabilir. Adanmışlık düzeyi yükselen öğretmenler eğitim öğretim faaliyetlerinde daha etkili olacak, bu öğretmenlerin performansları artacak, motivasyonları yükselecek ve kendileri daha mutlu olacaklardır.

Yetki devri sayesinde çalışanların örgütsel, yönetsel ve iş memnuniyetleri ile cesaretleri artmakta, verimli olmaları sağlanmaktadır (Aytürk, 2000). Yetkilendirme, öğretmenlere gelişim sorumluluklarını alabilme, problemlerini çözebilme ve dolayısıyla seçim, sorumluluk, özerklik ve otorite elde etme firsatı sunmaktadır (Araç, 2009). Kendilerine yetki verilen çalışanlar daha istekli ve verimli çalışmaktadırlar. Yetki devriyle birlikte çalşanların inisiyatif alma, sorun çözme, karar verme ve iş yapma yetenekleri gelişmiş olmakta, mesleki gelişimleri sağlanarak bilgi ve becerileri artmakta, sorumluluk alma gereksinimleri karşılanmaktadır (Onaran, 1974). Nitekim yetkileri ve sorumlulukları artan çalışanlar kendilerini güçlendirilmiş hissetmektedirler (Arslantaş, 2007; Aytürk, 2000; Bozkurt, 2012; Konczack vd., 2000). Bu anlamda öğretmenlerin yetki devri boyutunda çoğu zaman güçlendirilmeleri olumlu bir sonuç olarak değerlendirilmektedir.

Yönetsel destek boyutunda Özdemir (2010), Derinbay (2011), Özdemir-Demirel (2012), Doğan (2014), Ertürk, Keskinkılıç Kara ve Zafer Güneş (2016), öğretmenlerin yönetsel destek algılarının yüksek, Dodanlığlu Irmak (2019) ise yönetici desteği algısının orta seviyede olduğu sonucuna ulaşmışlardır. Bu araştırmada ulaşılan sonuç ile literatürde ulaşılan sonuçların örtüştüğü görülmektedir. Yönetici desteği, iş tatmini ve örgütsel adanmışlı̆̆ pozitif etkileyen bir faktördür (Purcell vd., 2009). Yönetici desteği çalışanları duygusal yönden beslemekte, çalş̧anlarda bir güven ve bağl1lık duygusu oluşturmakta, oluşan bu güven ve bağlllık duygusu çalışanların, çalıştkları kurumun amaç ve hedeflerini gözetmelerini sağlamaktadır (Emhan vd., 2013). Okul yöneticilerinin desteğini alan öğretmenler okulun iyileştirilmesi, toplantılara katılımda istekli olma, meslektaşlara yardımda bulunma gibi örgütsel vatandaşlık davranışlarını daha fazla göstermektedirler (Özdemir, 2010). Yönetici desteğinin öğretmenlere sağladığı tüm bu katkılardan dolayı öğretmenlerin okul yöneticileri tarafindan yüksek düzeyde güçlendirilmelerinin oldukça önemli olduğu düşünülmekte olup, okul yöneticilerinin yönetsel destek boyutunda öğretmenleri güçlendirmelerinin gerekli olduğu söylenebilir.

Karara katılım boyutunda Özdoğru (2012) ve Alanoğlu (2019), öğretmenlerin karara katılma düzeylerinin "düşük"; İnandı ve Gılıç (2016), orta; Demirtaş ve Alanoğlu (2015) yüksek; Olorunsola ve Olayemi (2011) "çok yüksek" düzeyde olduğu sonucuna ulaşmışlardır. Yapılan bazı çalışmalar (Gülcan, 2011; Küçükali, 2006) incelendiğinde öğretmenlerin karara katılım sürecine dâhil edilmediği ortaya çıkmaktadır. Babadoğan ve Yılmaz (2012) öğretmenlere katılım imkânı sunulduğu ve öğretmenlerin karara katılımının kararların niteliğini iyileştirdiği sonucuna ulaşmışlardır. Demirtaş ve Alanoğlu (2015) öğretmenlerin eğitimsel ve yönetimsel kararlara "bazen" düzeyinde katıldıklarını, Aksay ve Ural (2008), Karagöz (2009), Turgut (2010), Başar (2017) ve Başaran (2017), öğretmenlerin daha çok öğretimsel kararlara katıldıklarını, yönetimsel kararlara daha az ve düşük düzeyde katıldıklarını belirtmişlerdir. Bilge (2008) tarafından yapılan çalışmada, öğretmenlerin okul yöneticileri tarafından öğretimsel anlamda alınan kararlara katılımlarının sağlanmadığı belirlenmiş̧tir. Yapılan çalışmalarda genel olarak öğretmenlerin karara katılım düzeylerinin "düşük" olduğu görülmektedir. Özellikle yönetsel kararlarda katılımın düşük olduğu söylenebilir. Okulda yapılan birçok faaliyetin yönetim tarafindan alınan kararlar sonucu uygulandığı göz önüne alındığında öğretmenlerin yönetsel anlamda alınan kararlara katılımları, kararların uygulanmasını kolaylaştıracak ve öğretmenlerin daha istekli çalışmalarını sağlayacaktır. Çünkü karara yeterli düzeyde katılım, çalışanların örgütü ile bütünleşip sosyalleşmelerini, örgüt kültürünü ve değerlerini benimsemelerini sağlamaktadır (Ulutaş, 2011). Çalışanlar düşüncelerini açıkça dile getirdiği ve bu düşünceleri alınan kararlarda yer bulduğu ölçüde kendilerini önemli ve değerli hissedecekler ayrıca oluşumunda pay sahibi oldukları bu kararları uygulama konusunda daha istekli olacaklardır (Gümüş, 2011). Katılımcı yönetim anlayışının sergilendiği örgütlerde çalışanlar kendilerine içsel ödül verildiğini düşünmekte ve böylece motivasyon düzeylerinin yanında iş doyumu düzeyleri de yükselmektedir (Chisht vd., 2010). Alınan kararların etkili olması, okul yönetimlerinin katılımcı yönetim uygulamalarını yaygınlaştıracak politika ve uygulamalara yer vermesini ve karar alma sürecinin daha katılımcı olmasını gerektirmektedir. (Üzüm \& Kurt, 2019). Öğretmenlerin karar verme sürecine katılması kararların kalitesini arttırmakta, okulun sosyal kapasitesini güçlendirmekte, öğretmenlerin iş doyumu ve motivasyon düzeylerini yükseltmektedir (Hoy \& Miskel, 2010; Özdoğru \& Aydın, 2012; Wadesango, 2012). Dolayısıyla öğretmenlerin karara katılımlarının "çoğu zaman" düzeyinde çıkması öğretmen güçlendirmede önemli bir faktör olarak düşünülebilir. Çünkü karara katılım göstererek güçlendirilen öğretmenin bireysel performansı artacak bu durum da öğrenci ve dolayısıyla okulun eğitim başarısını yükseltecektir.

Alanyazında rastlanılan takım çalışmalarıyla ilgili bazı çalışmalarda (Ceylan, 2006; Güçlü \& Okçu, 2015; Günal, 2007) öğretmenlerin okullarda takım çalışmalarının yapıldığı görüşüne "katılıyorum" yönünde, bazı çalışmalarda (Kaldırım, 2003; Taşdan, 2007) "çoğu zaman" düzeyinde görüş belirttikleri, bazı çalı̧malarda ise (Günbayı \& Çevik, 2004; Tuna, 2003) öğretmenlerin takım çalışmalarına yönelik algılarının "yüksek" düzeyde olduğu 
görülmektedir. Alanyazındaki çalışmalarla bu araştırmanın sonuçlarının örtüştüğü görülmektedir. Okul yöneticilerinin takım çalışmalarını kolaylaştırması ve desteklemesi öğretmenlerin amaçlara odaklanmalarına, öz eleştiri yapmalarına ve birbirlerini desteklemelerine katkı sağlamaktadır (Malone \& McPherson, 2004). Takım lideri olarak okul yöneticileri, takım çalışmalarına liderlik edip bu çalışmaların başarıya ulaşması için okulda olumlu bir atmosfer oluşturmalı ve öğretmenlerin motivasyonlarını yüksek düzeye getirmek için çaba göstermelidirler (Ertürk \& Argon, 2019). Öğretmenler takım çalışmalarında iş birliği içinde çalışarak birbirine saygı göstermeyi öğrenmekte, yeteneklerini ve fikirlerini uygulama firsatı bulmakta ve dolayısıyla öğretmenlerin performansları da artmaktadır (Alagöz, 2007). Takım çalışmalarında üyelerin takım arkadaşlarına, işlerine ve örgütlerine karşı sergiledikleri olumlu tutum ve davranışlar onların örgütlerine adanmışlıklarını da artırmaktadır (Bülbül, 2007). Nitekim bu durumların öğretmenlerin örgütsel adanmışlıklarını da destekleyeceği düşünülmektedir. Çünkü işbirliği, saygı ve desteğin olduğu okul ortamında öğretmenlerin birbirine karş1 adanmışılıklarının da artacağı, bunun sonucunda okula ve öğretim işlerine adanmışlık düzeylerinin daha yüksek olacağı ve öğretim işlerinin yürütülmesinde fazla gayret gösterecekleri söylenebilir. Bu bağlamda öğretmenlerin güçlendirilmesinde takım çalışmalarının oldukça önemli olduğu düşünülebilir.

Öğretmenlerin iletişim boyutunda okul yöneticileri tarafindan "çoğu zaman" düzeyinde güçlendirilmeleri, iletişimin fonksiyonları olan kontrol, motivasyon, duygu ve düşüncelerin ifade edilmesi, bilgi edinme ve bilgi paylaşımının öğretmenlere sağlandığının göstergesidir (Robbins, 2003). Alanyazında bazı çalışmalarda da okul yöneticilerinin iletişim becerilerinin "orta" düzeyde olduğu (Memduhoğlu, 2015; Uzun \& Ayık, 2016), bazı çalışmalarda (Akan \& Mehrdad, 2019; Sağır \& Parlak, 2018; Uzun, 2015) "iyi" düzeyde olduğu fakat bazı yönlerinin geliştirilmesi gerektiği, bazı çalışmalarda ise (Doğan vd., 2016; Şanlı vd., 2014) okul yöneticilerinin "etkili" ve "yüksek" düzeyde bir iletişim becerisine sahip oldukları sonucuna ulaşılmıştır. Belirtilen çalışmalarda ulaşılan sonuçlar, bu araştırmada ulaşılan öğretmenlerin iletişim boyutunda "çoğu zaman" güçlendirilmekte oldukları sonucuyla örtüşmektedir. İletişim yönetsel ve örgütsel faaliyetlerin başarılı bir şekilde yürütülmesinde (Genç, 2005), bireylerin birbirlerini etkilemesi ve grup olarak hareket etmesinde oldukça önemli bir yere sahiptir (Pradhan \& Chopra, 2008). Okul yöneticilerinin, öğretmenleri iletişim boyutunda güçlendirmelerinin okullardaki planlama, koordinasyon, paylaşım, motivasyon, katılım, iş birliği takım çalışması gibi süreçlerin etkili ve verimli olmasında oldukça önem taşımakta olduğu söylenebilir. Bundan dolayı öğretmenlerin adanmışlıklarında da okul yöneticilerinin onları iletişim boyutunda güçlendirmelerinin önemli olduğu düşünülmektedir.

\section{2. Öğretmenlerin örgütsel adanmışlık algılarına yönelik tartışma ve sonuç}

Öğretmenlerin örgütsel adanmışlık algıları; ölçek geneli ile okula adanma, öğretim işlerine adanma, öğretmenlik mesleğine ve çalışma grubuna adanma boyutlarının tamamında "yüksek" düzeydedir. Öğretmenlerin örgütsel adanmışlık düzeyleri, öğretim işlerine adanma ve öğretmenlik mesleğine adanma boyutlarında diğerlerine göre yüksektir. Daha sonra sırasıyla okula adanma ve çalışma grubuna adanma boyutları gelmektedir. Bu sonuç, öğretmenlerin bir meslek olarak öğretmenlik ile okuldaki öğretmenlik kavramlarını farklı algıladıklarını göstermektedir.

Kalaz (2016), öğretmenlerin örgütsel adanmışlıklarının "kısmen katılıyorum" düzeyinde; Döş (2014), Doğan (2015) ve Mamaç (2019) "orta" düzeyde; Altunel (2015), Aytekin (2016), Doğan ve Aslan (2016), Altunay (2017), Sivik (2018) ve Alim (2019) bu araştırmanın sonucunu destekler nitelikte "yüksek" düzeyde; Düzener (2006), Karagöz (2008), Alper Apak (2009) ve Arslanhan (2014) ise "çok yüksek" düzeyde olduğunu tespit etmişlerdir. Celep vd. (2004) ve Aytekin (2016) tarafindan yapılan çalışmalarda da öğretmenlerin örgütsel adanmışlık ve tüm alt boyutlarına yönelik algılarının yüksek düzeyde olduğunun tespit edilmesi, bu araştırmanın sonuçlarının literatür tarafından desteklendiğini göstermektedir. Ertürk (2011), Babaoğlan ve Ertürk (2013), çalışmalarında öğretmenlerin okula ve çalışma grubuna adanmışlıklarının "yüksek", öğretim işlerine ve öğretmenlik mesleğine adanmışlıklarının "çok yüksek", Zöğ (2007), okula ve öğretmenlik mesleğine adanmışlıklarının "yüksek", Düzener (2006), öğretim işlerine adanmışlıklarının "yüksek" düzeyde olduğunu saptamıştır. Örgütsel adanmışlık ve alt boyutlarına yönelik literatürdeki sonuçlarla bu araştırmanın sonuçlarının benzerlik göstermesi olumlu bir durum olarak görülebilir. Çünkü örgüte adanmışlık düzeyi yüksek olan çalışanlar, daha verimli ve başarılı olmalarının yanı sıra işten ayrılma, işe devamsızlık, stres gibi örgütle ilgili olumsuz tutum ve davranışları daha az göstermektedirler (Aytekin, 2016). Örgütsel adanmışlık, çalışanların işyeri tutumlarının olumlu yönde seyretmesini de beraberinde getirmektedir. Örgütsel adanmışlık ile birlikte çalş̧anların iş tatmini, motivasyon, performans, örgütsel bağlılık, örgütsel vatandaşlık davranışı gibi pek çok konuda olumlu bir tutum sergilemesi beklenmektedir (Özy1lmaz \& Süner, 2015). Okulların etkili ve verimli olabilmesi, öğretmenlerin örgütsel adanmışlıklarının artırılması için okul yöneticileri tarafından öğretmenlere yetki verilmeli, takım çalışmaları desteklenmeli, yönetsel destek ve öğretmenlerin karara katılımı sağlanmalı, okul yöneticileri öğretmenlerle yapıcı ve açık bir iletişim kurmalıdır. 


\section{3. Öğretmenlerin davranışsal güçlendirilmesi ile örgütsel adanmışlı algıları arasındaki ilişkiye yönelik tartışma ve sonuç}

Öğretmenlerin davranışsal güçlendirme ölçeği toplam puanları ile örgütsel adanmışlık ölçeği toplam puanları arasında orta düzeyde ve pozitif yönlü anlamlı bir ilişki vardır. Öğretmenlerin okul yöneticileri tarafindan güçlendirilmelerine yönelik algıları yükseldikçe örgütsel adanmışlık düzeyleri de yükselmektedir. Puncreobutr ve Watttanasan (2016), bu araştırmanın sonucunu destekler nitelikte, yapısal güçlendirme ile örgütsel adanmışlık arasında yüksek düzeyde anlamlı bir ilişki olduğunu saptamışlardır. Literatürde öğretmenlerin davranışsal güçlendirilmesi ile örgütsel adanmışlığın birlikte ele alındığ 1 çalışma bulunmamasına rağmen güçlendirme (Aliakbari \& Amoli, 2016; Bogler \& Somech, 2004; Chebet, 2013; İhtiyarlığlu, 2017; Kıral, 2015; Öznacar vd., 2016; Taş, 2017) ve örgütsel adanmışlığın farklı değişkenlerle ele alındığı çalışmalar (Altunay, 2017; Döş, 2014; Ertürk, 2011; Kalaz, 2016; Uzun, 2011; Zhu vd., 2004) vardır.

Davranışsal güçlendirme ölçeği geneli ile örgütsel adanmışlı ölçeğinin okula adanma, öğretim işlerine adanma ve çalı̧̧ma grubuna adanma boyutları arasında pozitif yönlü ve orta düzeyde, öğretmenlik mesleğine adanma boyutu arasında pozitif yönlü ve düşük düzeyde anlamlı bir ilişki vardır. Davranışsal güçlendirme ölçeği geneli ve örgütsel adanmışlık ölçeği geneli ile boyutları arasındaki ilişki en yüksek düzeyde, okula adanma boyutunda, daha sonra sırasıyla örgütsel adanmışlık ölçeği geneli, öğretim işlerine adanma ve çalışma grubuna adanma boyutlarında orta düzeyde, öğretmenlik mesleğine adanma boyutunda ise düşük düzeydedir.

Araştırma sonucuna göre en yüksek düzeyde ilişki, davranışsal güçlendirme ölçeği geneli ve boyutları ile örgütsel adanmışlığın okula adanma boyutu ve örgütsel adanmışlık arasındadır. Bu sonuç, öğretmenlerin örgütsel kimlik algılarının yüksek düzeyde olduğunu ve okul imajlarını koruma eğiliminde olduklarını göstermektedir. Örgütsel kimlik, örgüt ile çalışanlar arasındaki güçlü, psikolojik bir bağdır. Bu bağ, örgütsel bağglılı̆̆ın ötesinde gerçekleşmekte ve çalışanların güçlenmesine de katkı sağlamaktadır (Basar \& Sigri, 2015). Örgütsel imaj ise, örgütün kamuoyundaki algılanma biçimi (Okay, 2000), örgüt ve kamuoyu ilişkisinde önemli bir referans olarak ortaya çıkan örgütün insanların akıllarındaki resmidir (Gürbüz, 2008). Davranışsal güçlendirme ve boyutları ile öğretmenlerin okula adanmışlı̆ı arasındaki ilişki düzeyinin, öğretim işlerine, öğretmenlik mesleğine ve çalışma grubuna adanmışlık arasındaki ilişki düzeylerinden daha yüksek ortaya çıması, öğretmenlerin okul ile oluşturdukları psikolojik bağdan ve okullarının kamuoyundaki algılanış biçimlerinden kaynaklanmış olabilir. Ayrıca kurumsal imaj, çalışanların performans, motive olma, işbirliği, iş doyumu, bağllılık ve özdeşleşme algılarını pozitif etkilemekte olduğu için (Polat, 2009) öğretmenlerin okul imajlarına yönelik olumlu bakış açıları da güçlendirme ile okula adanmışlıkları arasındaki ilişkilerin düzeyini yükseltmiş olabilir. Örgütsel imaj, çalışanların örgütle bağ kurup özdeşleşmelerini güçlendirebilmektedir (Özgözgü, 2016). Öğretmenler rahat çalışma ortamının, okul etkililiğinin ve hizmet kalitesinin okulun imajını artırdığını düşünmektedirler (Başar vd., 2014). Dolayısıyla öğretmenlerin güçlendirilmeleri ile okula adanmışlıkları ve örgütsel adanmışlıkları arasındaki ilişkilerin öğretim işlerine, öğretmenlik mesleğine ve çalışma grubuna adanmışlık arasındaki ilişkilerden daha yüksek düzeyde olması normal karşılanabilir. Çünkü güçlendirilen öğretmenlerin okullarında rahat bir çalışma ortamı elde etmeleri ve böylece verimli olmaları beklenmektedir.

Sonuç olarak öğretmenlerin okul yöneticileri tarafindan güçlendirilmelerine yönelik algıları yükseldikçe örgütsel adanmışlık düzeyleri de yükselmektedir. Literatürde öğretmenlerin güçlendirilmesi ve örgütsel adanmışlığının farklı unsurlarla ilişkili olduğu, hem güçlendirmenin hem de adanmışlığın farklı değişkenleri etkilediği ve farklı değişkenlerden etkilendiği görülmektedir. $\mathrm{Bu}$ nedenle okul yöneticileri okul yönetiminde bu değişkenler arasındaki ilişkileri ve etkileri göz önünde bulundurmalıdırlar.

\section{5. ÖNERILER}

Bu bölümde araştırmanın sonuçları çerçevesinde uygulamaya ve araştırmacılara yönelik öneriler sunulmuştur.

\subsection{Uygulamaya yönelik öneriler}

1- Öğretmenlerin davranışsal açıdan güçlendirilmelerinde özellikle yönetsel açıdan güçlendirilmelerine katkı sağlayacak olan yetki devri boyutunda, okul yöneticileri sahip oldukları yetki ve inisiyatifleri çerçevesinde öğretmenleri işlerin yapılmasında ve kendi sorumluluk alanları ile ilgili problemlerinin çözümünde daha fazla yetkili kılarak öğretmenlerde problem çözümünde yeterli oldukları hissinin oluşmasını ve öğretmenlerin yeteneklerinin ortaya çıkmasını sağlayabilir, karara katılım boyutunda, öğretmenlerin görüş ve önerilerine değer vererek onları ilgilendiren konularda karara katılımlarını sağlayabilir.

2- Öğretmenlerin örgütsel adanmışlık algılarının yükseltilmesi konusunda, özellikle okula ve çalışma grubuna adanma boyutları açısından yapılabilecekler şu şekilde sıralanabilir:

3- a) Okula adanma boyutunda, mesleğe veya okuldaki görevine yeni başlayan öğretmenlere oryantasyon programları düzenlenebilir, öğretmenlerin okul üyeliğine katkı sağlayacak sosyal aktivitelere katılımları teşvik edilebilir. 
4- b) Çalışma grubuna adanma boyutunda, öğretmenler odasında ahenkli ortam oluşturulabilir, öğretmenlerin birlikteliğini sağlayıcı etkinliklerin (piknik, gezi, yemek, sinema, tiyatro) yanında özel günlerde (düğün, kına, bayram, ölüm, doğum günü, terfi) de öğretmenlerin bir arada olması sağlanabilir.

5- Öğretmenlerin davranışsal açıdan güçlendirilmesi örgütsel adanmışlıklarına önemli bir katkı sağlayabilir.

\subsection{Araştırmacılara yönelik öneriler}

1- Öğretmenlerin davranışsal güçlendirme ve örgütsel adanmışlık konuları ile ilgili algı ve beklentilerinin ortaya çıkarılması ve karşılaştırılmasına yönelik nitel ve nicel araştırmalar yapılabilir.

2- Öğretmenlerin davranışsal güçlendirilmesi ve örgütsel adanmışlık konularının farklı konularla ilişkilendirildiği veya bu iki konu arasında aracılık rolü oynayabilecek farklı konuların yer aldığ araştırmalar yapılabilir. 


\section{KAYNAKÇA}

Ada, Ş., Akan, D., Ayık, A., Yıldırım, İ. \& Yalçın, S. (2013). Öğretmenlerin motivasyon etkenleri. Atatürk Üniversitesi Sosyal Bilimler Enstitüsü Dergisi, 1(3), 151-166.

Akan, D. \& Mehrdad, A. (2019). Okul Müdürlerinin iletişim becerilerinin öğretmen algılarına göre incelenmesi. Nevşehir Hacı Bektaş Veli Üniversitesi SBE Dergisi, 9(1), 287-300.

Aksay, O. \& Ural, A. (2008). Ortaöğretim öğretmenlerinin okulla ilgili kararlara katılımı. Türk Eğitim Bilimleri Dergisi, 6(3), 433-460.

Alagöz, K. (2007). Mesleki ve teknik eğitimde takım çalışmast ve eğiticilerin performansına etkisi [Yüksek lisans tezi, Beykent Üniversitesi]. https://tez.yok.gov.tr/UlusalTezMerkezi/

Alanoğlu, M. (2019). Algllanan okul müdürü yönetim tarzlart ile ögretmenlerin karara katılma, örgütsel adalet, iş doyumu ve tükenmişlik algıları arasındaki ilişkinin analizi [Doktora tezi, Fırat Üniversitesi]. https://tez.yok.gov.tr/UlusalTezMerkezi/

Aliakbari, M., \& Amoli, F. A. (2016) The effects of teacher empowerment on teacher commitment and student achievement. Mediterranean Journal of Social Sciences, 7(4), 649-657. https://doi.org/10.5901/mjss.2016.v7n4p649

Alim, N. (2019). Öğretmenlerin algılarına göre ögretmen liderliği ile örgütsel adanmışlık arasındaki ilişkinin incelenmesi [Yüksek lisans tezi, Recep Tayyip Erdoğan Üniversitesi]. https://tez.yok.gov.tr/UlusalTezMerkezi/

Alper Apak, E. G. (2009). Ylldırma eylemleri ve örgütsel adanmışllk ilişkisi: İlköğretim okulu ögretmenleri üzerinde bir araştirma [Yüksek lisans tezi, Marmara Üniversitesi]. https://tez.yok.gov.tr/UlusalTezMerkezi/

Altunel, A. T. (2015). Örgütsel güven düzeyi ile örgütsel adanmışlı düzeyi arasındaki ilişki: Bir araştırma [Yayımlanmamış yüksek lisans tezi]. İnönü Üniversitesi.

Altunay, E. (2017). İlköğretim okulu öğretmenlerinin örgütsel güven ve adanmışlık düzeyleri arasındaki ilişkinin incelenmesi. Milli Ĕgitim Dergisi, 46(213), 37-66.

Appelbaum, S. H., Hebert, D., \& Leroux, S. (1999). Empowerment: Power, culture and leadership-a strategy or fad for the millennium. Journal of Workplace Learning: Employee Counselling Today, 11(7), 233254.

Araç, N. B. (2009). Sinıf ögretmenlerinin örgütsel bağlllık ve yetkilendirilmeye ilişskin görü̈şleri [Yüksek lisans tezi, Anadolu Üniversitesi]. https://tez.yok.gov.tr/UlusalTezMerkezi/

Arslanhan, Ü. N. (2014). Ortaokul ögretmenlerinin yıldırma eylemlerine maruz kalma durumlart ile örgütsel adanmışlikları arasındaki ilişkinin incelenmesi [Yüksek lisans tezi, Kahramanmaraş Sütçü İmam Üniversitesi]. https://tez.yok.gov.tr/UlusalTezMerkezi/

Arslantaş, C. C. (2007). Güçlendirici lider davranışının psikolojik güçlendirme üzerindeki etkisini belirlemeye yönelik görgül bir araştırma. Anadolu Üniversitesi Sosyal Bilimler Dergisi, 7(2), 227-240.

Aytekin, M. (2016). Lider üye etkileşiminin örgütsel adanmışlı üzerine etkisi [Yüksek lisans tezi, Süleyman Demirel Üniversitesi]. https://tez.yok.gov.tr/UlusalTezMerkezi/

Aytürk, N. (2000). Yönetimde yetki devri ve imza yetkileri. Amme İdaresi Dergisi, 33(1), 79-110.

Babaoğlan, E. \& Ertürk, E. (2013). Öğretmenlerin örgütsel adalet algısı ile örgütsel adanmışlıkları arasındaki ilişki. Hacettepe Üniversitesi Ĕgitim Fakültesi Dergisi, 28(2), 87-101.

Babadoğan, E. \& Yılmaz, F. (2012). İlköğretim okullarında karara katılma. Mersin Üniversitesi Eğitim Fakültesi Dergisi, 8(3), 1-12.

Balc1, A. (2003). Örgütsel sosyalleşme kuram strateji ve taktikler (2. baskı). Pegem A Yayıncılık.

Barnard, I. C. (1982). The functions of the executive. Harvard University.

Basar, U., \& Sigri, Ü. (2015). Effects of teachers' organizational justice perceptions on intention to quit: Mediation role of organizational İdentification. Educational Sciences: Theory and Practice, 15(1), 4559 .

Başar, M., Şahin, C. \& Akan, D. (2014). Okulların entelektüel sermayeleri ile örgütsel imajları arasındaki ilişkinin öğretmen görüşlerine göre incelenmesi. Akademik Sosyal Araştırmalar Dergisi, 2(2), 302317.

Başar, P. (2017). Katılımcı yönetimin iş doyumu üzerine etkisi: Akademik personel üzerinde bir araştırma. JEBPIR, 3(1), 1-34.

Başaran, A. (2017). Öğretmenlerin karara katılma durumlarının farklı değişkenlere göre incelenmesi [Yüksek lisans tezi]. Yıldız Teknik Üniversitesi.

Baysal, A. C. \& Paksoy, M. P. (1999). Mesleğe ve örgüte bağlllı̆̆ın çok yönlü incelenmesinde Meyer-Allen modeli. I. Ü. İşletme Fakültesi Dergisi, 28(1), 7-15.

Bedük, A. (2012). Karşılaş̧tırmalı işletme-yönetim terimleri sözlüğü (3. baskı). Nobel Yayıncıllk.

Bilge, C. (2008). Illkögretim okulu ögretmenlerinin karara katılma ve iş doyum düzeyleri arasındaki ilişki [Yüksek lisans tezi, Gazi Üniversitesi]. https://tez.yok.gov.tr/UlusalTezMerkezi/ 
Bogler, R., \& Somech, A. (2004). Influence of teacher empowerment on teachers organizational commitment, professional commitment and organizational citizenship behavior in schools. Teaching \& Teacher Education, 20(3), 277-289.

Boylu, Y., Pelit, E. \& Güçer, E. (2007). Akademisyenlerin örgütsel bağlllık düzeyleri üzerine bir araştırma. Finans Politik ve Ekonomik Yorumlar, 44(511), 55-74.

Bozdemir, Y. (2012). Okul yöneticilerinin örgütsel adanmışlık düzeyleri ile problem çözme becerileri arasındaki ilişki [Yüksek lisans tezi, Kastamonu Üniversitesi]. https://tez.yok.gov.tr/UlusalTezMerkezi/

Bozkurt, F. G. (2012). Yetki devrinin psikolojik güçlendirme ve amirin algılanan sosyal kaytarması ile ilişkisinde amire duyulan güvenin düzenleyici etkisi [Doktora tezi, Hacettepe Üniversitesi]. https://tez.yok.gov.tr/UlusalTezMerkezi/

Bredeson, P. V., \& Johansson, O. (2006). The school principal's role in teacher professional development. Journal of In-Service Education, 26(2), 385-401.

Bülbül, M. (2007). Örgütsel bağlllık ve kamu kuruluşlarına yönelik araştırma [Yüksek lisans tezi, Kahramanmaraş Sütçü İmam Üniversitesi]. https://tez.yok.gov.tr/UlusalTezMerkezi/

Büyüköztürk, Ş. (2011). Sosyal bilimler için veri analizi el kitabı. PegemA Akademi.

Caymaz, E., Erenel, F. \& Gürer, B. (2013). Liderlik karizması, adanmışlık ve gruba aidiyetin gönüllü çalışma performansına etkileri: Akut arama kurtarma derneği örneği. International Journal of Human Sciences, 10(1), 129-147.

Celep, C. (2000). Ĕgitimde örgütsel adanma ve öğretmenler. Anı Yayıncılık.

Celep, C. (2014). Eğitim örgütlerinde örgütsel adanma (2. bask1). Nobel Akademik Yayınc1lık.

Celep, C., Doyuran, Ş., Sarıdede, U. \& Değirmenci, T. (2004, Temmuz 6-9). Eğitim örgütlerinde çok boyutlu iş etiği ve örgütsel adanmışlık [Sözlü Bildiri]. XIII. Ulusal Eğitim Bilimleri Kurultayı, Türkiye.

Ceylan, S. (2006). İlköğretim okulu yönetici ve öğretmenlerinin takım çalışmasına ilişkin algıları (Balıkesir ili Burhaniye örne ği) [Bilim uzmanlığı tezi]. İnönü Üniversitesi.

Chebet, R. (2013). Empowerment of teachers and performance of private secondary schools in bome county, Kenya [Master's thesis, University of Nairobi School of Business]. http://erepository.uonbi.ac.ke/

Chishti S. H., Rafiq, M., Rahman, F., Jumani, N. B., \& Ajmal, M. (2010). Impact of participative management on employee job satisfaction and performance in Pakistan. Language in India, 10(12), 89-101.

Conger, J. A., \& Kanungo R. N. (1988). The empoverment process: Integraring theory and practice. Academy of Management Review, 13(2), 471-482.

Dee, J. R., Henkin, A. B., \& Duemer, L. (2002). Structural antecedents and psychological correlates of teacher empowerment. Journal of Educational Administration, 41(3), 257-277.

Demirtaş, Z. \& Alanoğlu, M. (2015). Öğretmenlerin karara katılımı ve iş doyumu arasındaki ilişki. Ahi Evran Üniversitesi Kırşehir Ĕ̈itim Fakültesi Dergisi, 16(2), 83-100.

Derinbay, D. (2011). İlkögrretim okullarında görev yapan ögretmenlerin algıladıkları örgütsel destek düzeyleri [Yayımlanmamış yüksek lisans tezi]. Pamukkale Üniversitesi.

Dewettinck, K., \& Van Ameijde, M. (2011). Linking leadership empowerment behavior to employee attitudes and behavioral intentions: Testing the mediating role of psychological empowerment. Personnel Review, 40(3), 284-305.

Dodanlığlu Irmak, S. (2019). Isşyerinde psikolojik taciz ile tükenmişlik, işten ayrılma niyeti ve algılanan yönetici desteği ilişkisi üzerine bir araştırma [Yüksek lisans tezi, Marmara Üniversitesi]. https://tez.yok.gov.tr/UlusalTezMerkezi/

Doğan, S. (2014). Illkokullarda görev yapan ögretmenlerin örgütsel destek alglsı (Polatlı ilçesi örneği) [Yüksek lisans tezi, Hacettepe Üniversitesi]. https://tez.yok.gov.tr/UlusalTezMerkezi/

Doğan, S., Çetin, Ş. \& Koçak, O. (2016). Okul yöneticilerinin iletişim becerilerine ilişkin öğretmenlerin algı ve görüşleri. Kuramsal Eğitimbilim Dergisi, 9(1), 57-84.

Doğan, Ü. (2015). Özel ĕgitim kurumlarında çalışan öğretmenlerin örgütsel adanmışlık düzeyleri ile müdürlerinin hizmetkâr liderlik davranışları arasındaki ilişki [Yüksek lisans tezi, Ondokuz Mayıs Üniversitesi]. https://tez.yok.gov.tr/UlusalTezMerkezi/

Doğan, Ü. \& Aslan, H. (2016). Özel eğitim kurumlarında çalışan müdürlerin hizmetkâr liderlik davranışları ile öğretmenlerin örgütsel adanmışlık düzeyleri arasındaki ilişki. Ondokuz. Mayıs Üniversitesi Eğitim Fakültesi Dergisi, 35(2), 51-68.

Döş, F. C. (2014). Okul müdürlerinin liderlik stillerinin öğretmenlerin örgütsel adanmışlıkları üzerindeki etkisinin incelenmesi [Yüksek lisans tezi, Kahramanmaraş Sütçü İmam Üniversitesi]. https://tez.yok.gov.tr/UlusalTezMerkezi/

Düzener, S. (2006). Özel ilk ve ortaögretim okullarında toplam kalite yönetimi uygulamasının yönetici ve ögretmenlerin örgütsel adanmışlık düzeyine etkisi [Yüksek lisans tezi, Yeditepe Üniversitesi]. https://tez.yok.gov.tr/UlusalTezMerkezi/ 
Eisenberger, R., Fasolo, P., \& Davis-LaMastro, V. (1990). Perceived organizational support and employee diligence, commitment, and innovation. Journal of Applied Psychology, 75(1), 51-59. https://doi.org/10.1037/0021-9010.75.1.51

Emhan, A., Kula, S. \& Töngür, A. (2013). Yapısal eşitlik modeli kullanılarak yönetici desteği, örgütsel bağl1lık, örgütsel performans ve tükenmişlik kavramları arasındaki ilişkilerin analizi: Kamu sektöründe bir uygulama. Hacettepe Üniversitesi İktisadi ve İdari Bilimler Fakültesi Dergisi, 3(1), 53-69.

Ertürk, A., Keskinkılıç Kara, S. B. \& Zafer Güneş, D. (2016). Duygusal emek ve psikolojik iyi oluş: Bir yordayıcı olarak yönetsel destek algısı. Abant İzzet Baysal Üniversitesi Ë̆itim Fakültesi Dergisi, 16(4), 1723-1744.

Ertürk, E. (2011). İlköğretim ve ortaögretim okullarındaki örgütsel adalet alglsı ile öğretmenlerin örgütsel adanmışlıkları arasındaki ilişki [Yüksek lisans tezi, Mehmet Akif Ersoy Üniversitesi]. https://tez.yok.gov.tr/UlusalTezMerkezi/

Ertürk, R. \& Argon T. (2019, Nisan 25-28). Öğretmen görüşlerine göre okullarda takım çalışmaları ve sosyal kaytarma [Sözlü bildiri]. 28. Uluslararası Eğitim Bilimleri Kongresi, Türkiye.

Genç, N. (2005). Yönetim ve organizayon-çağdaş sistemler ve yaklaşımlar. Seçkin Yayıncılık.

Güçlü, H. (2006). Turizm sektöründe durumsal faktörlerin örgütsel bağlllık üzerindeki etkisi. Anadolu Üniversitesi Turizm ve Otel İşletmeciliği Yüksekokulu Yayınları.

Güçlü, N. \& Okçu, V. (2015). İlköğretim öğretmenlerinin etkili takım çalışmasına ilişkin algıları ile örgütsel bağlılıkları arasındaki ilişki. YYÜ Ĕgitim Fakültesi Dergisi, 12(1), 49-69.

Gülcan, M. G. (2011). Views of administrators and teachers on participation in decision making at school: The city of Ankara sample. Education, 131(3), 637-652.

Gümüş, E. A. (2011). Illkögrretim okullarında çalışan ögretmenlerin yönetime katılma düzeyleri ile örgüt kültürü ilişkisinin incelenmesi [Yüksek lisans tezi, Yeditepe Üniversitesi]. https://tez.yok.gov.tr/UlusalTezMerkezi/

Günal, N. (2007). Illkögrretim okulu yönetici ve öğretmenlerinin takım algısı düzeylerinin incelenmesi [Yüksek lisans tezi, Dokuz Eylül Üniversitesi]. https://tez.yok.gov.tr/UlusalTezMerkezi/

Günbayı, İ. \& Çevik, V. (2004). Yönetici ve öğretmenlerin toplam kalite yönetimine ilişkin görüşleriyle ilgili bir araştırma. Milli Ĕ̈itim Dergisi, https://dhgm.meb.gov.tr/yayimlar/dergiler/Milli_Egitim_Dergisi/163/gunbayi.htm

Gürbüz, S. (2008). Yönetici, ögretmen ve velilere göre Ankara ili özel ve kamu ilköğretim okullarının kurumsal imajı [Yayımlanmamış doktora tezi]. Ankara Üniversitesi.

Hales, C., \& Klidas, A. (1998). Empowerment in five-stars hotels: Choice, voice or rhetoric? International Journal of Contemporary Hospitality Management, 10(3), 88-95.

Herrenkohl, R. C., Judson, G. T., \& Heffner, J. A. (1999). Defining and measuring employee empowerment. The Journal of Applied Behavioral Science, 35(3), 373-389.

Hoy, W. K., \& Miskel, C. G. (2010). Eğitim yönetimi: Teori, araştırma ve uygulama (Çev. Ed. S. Turan, 7. bask1). Nobel. (Orijinal çalışma 2004 yılında yayımlandı.)

İhtiyaroğlu, N. (2017). Yapısal ve psikolojik güçlendirmenin öğretmen motivasyonu üzerindeki etkisi. Kırıkkale Üniversitesi Sosyal Bilimleri Dergisi, 7(2), 361-378.

İnand1, Y., \& Gılıç, F. (2016). Relationship of teachers' readiness for change with their participation in decision making and school culture. Educational Research and Reviews, 11(8), 823-833.

Kalaz, M. (2016). Öğretmen görüşlerine göre okul yöneticilerinin etik liderlik özellikleri ile ögrretmenlerin örgütsel adanmışlıklarl arasındaki ilişkinin incelenmesi [Yüksek lisans tezi, Yıldız Teknik Üniversitesi]. https://tez.yok.gov.tr/UlusalTezMerkezi/

Kaldırım, S. (2003). İlköğretim okullarındaki öğretmen ve yöneticilerin takım iklimine ilişkin görüşleri (İstanbul ili Beykoz ilçesi örneği) [Yüksek lisans tezi, Sakarya Üniversitesi]. https://tez.yok.gov.tr/UlusalTezMerkezi/

Karagöz, A. (2008). İlk ve orta ögretim okulu yöneticilerinin ögretmenler tarafindan algılanan etik liderlik rolleri ile öğretmenlerin örgütsel adanmışlıkları arasındaki ilişki (Bursa ili örneği) [Yüksek Lisans Tezi, Yeditepe Üniversitesi]. https://tez.yok.gov.tr/UlusalTezMerkezi/

Karagöz, M. E. (2009). Anadolu liselerinde görev yapan ögretmenlerin karara katılma durumları [Yüksek lisans tezi, Yıldız Teknik Üniversitesi]. https://tez.yok.gov.tr/UlusalTezMerkezi/

Karasar, N. (2005). Bilimsel araştırma yöntemi, ilkeler, teknikler. Nobel Yayınları.

Karasoy, H. A. (2011). Örgüt psikolojisi (1. bask1). Atlas Akademi Yayınları.

Kıral, B. (2015). Lise yöneticilerinin ögretmenleri güçlendirmesi ve ögretmenlerin kayıtsılık (sinizm) davranışı ile ilişkisi [Doktora tezi, Ankara Üniversitesi]. https://tez.yok.gov.tr/UlusalTezMerkezi/

Kilmen, S. (2015). Eğitim araştırmacıları için SPSS uygulamalı istatistik. Edge Akademi.

Klagge, J. (1998). The empowerment squeeze-views from the middle management position. The Journal of Management Development, 17(8), 548-558.

Koçel, T. (2005). İsletme yöneticiliği. Arıkan Basım Yayın. 
Koçel, T., Aysan M. A. \& Pekdemir I. (1991). Kamu iktisadi tesebbüslerinde yönetim üyeliği el kitabı. DPT Sosyal Planlama Başkanlığı.

Konczak, L. J., Stelly, D. J., \& Trusty, M. L. (2000). Defining and measuring empowering leader behaviors: Development of an upward feedback instrument. Educational and Psychological Measurement, 60(2), 301-313.

Küçükali, R. (2006). Avrupa Birliği yolunda yeni okul yöneticilerinin karar verme süreci [Yüksek lisans tezi, Atatürk Üniversitesi]. https://tez.yok.gov.tr/UlusalTezMerkezi/

Malone, D. M., \& Mcpherson, J. R. (2004). Community-and hospital-based early intervention team members' attitudes and perceptions of teamwork. International Journal of Disability, Development and Education, 51(1), 99-116.

Mamaç, M. (2019). Sınıf öğretmenlerinin mobbinge maruz kalma düzeyleri ile örgütsel adanmışlıkları arasındaki ilişkinin incelenmesi [Yüksek lisans tezi, Marmara Üniversitesi]. https://tez.yok.gov.tr/UlusalTezMerkezi/

Memduhoğlu, H. B. (2015). Öğretmen ve yönetici algılarına göre ilköğretim okulu yöneticilerinin iletişim becerileri. Ĕgitim ve Bilim, 40(177), 271-284.

Okay, A. (2000). Kurum kimliği (2. baskı). MediaCat Kitapları.

Olorunsola, E. O., \& Olayemi, A. O. (2011). Teachers participation in decision making process in secondary schools in ekiti state, Nigeria. International Journal of Education Administration and Policy Studies, 3(6), 78-84.

Onaran, O. (1974). Yetki göçerimi. Amme İdaresi Dergisi, 7(2), 3-21.

Ökmen, A. (2018). Öğretmen güçlendirmeye ilişkin lisede görev yapan ögretmenlerin algıları [Yüksek lisans tezi, Yıldız Teknik Üniversitesi]. https://tez.yok.gov.tr/UlusalTezMerkezi/

Özdamar, K. (2002). Paket programlar ile istatistik veri analizi. (4. bask1). Kaan.

Özdaşlı, K. (2002). Bilgi toplumu işletmelerinde yenilikçi özellikler [Yüksek lisans tezi, Süleyman Demirel Üniversitesi]. https://tez.yok.gov.tr/UlusalTezMerkezi/

Özdemir, A. (2010). İlköğretim okullarında algılanan yönetici desteğinin ve bireycilik-ortaklaşa davranışçıllı̆ın örgütsel vatandaşlık davranışı ile ilişkisi. Kuram ve Uygulamada Eğitim Yönetimi, 16(1), 93-112.

Özdemir-Demirel, G. (2012). Okul müdürlerinin güç kaynaklarını kullanma stilleri ve müdür desteğinin kurumsal vatandaşlık davranışıla ilişkisi (Ankara ili örneği) [Yüksek lisans tezi, Gazi Üniversitesi]. https://tez.yok.gov.tr/UlusalTezMerkezi/

Özdoğru, M. (2012). İlköğretim okulu ögretmenlerinin karara katılma durumları ve istekleri ile motivasyon düzeyleri arasındaki ilişki [Yayımlanmamış yüksek lisans tezi]. Abant İzzet Baysal Üniversitesi.

Özdoğru, M. \& Aydın, B. (2012). İlköğretim okulu öğretmenlerinin karara katılma durumları ve istekleri ile motivasyon düzeyleri arasındaki ilişki. Abant İzzet Baysal Üniversitesi Ĕ̌itim Fakültesi Dergisi, 12(2), 357-367.

Özgözgü, S. (2016). Kurumsal imaj, örgüt kültürü ve örgütsel özdeşleşme ilişkisi. Kastamonu Eğitim Dergisi, 25(2), 581-596.

Öznacar, B., Çoban, Ö. \& Yılmaz, E. (2016). Öğretmenlerin iş doyumlarının öğretmenlerin güçlendirilmesi ve bazı değişkenler açısından incelenmesi. O. Köksal (Ed.), l. International academic research congress book içinde (ss. 3978-3984). Antalya.

Özyılmaz, A. \& Süner, Z. (2015). İşe adanmışlığın işyeri tutumlarına etkisi: Hatay’daki 9 işletmede yapılan ampirik araştırmanın Sonuçları. Eskişehir Osmangazi Üniversitesi İktisadi ve İdari Bilimler Dergisi, 10(3), 143-164.

Polat, S. (2009, Mayıs, 1-3). Yüksekögrretim örgütlerinde örgütsel imaj yönetimi örgütsel imajın öncülleri ve çıktıları [Sözlü bildiri]. 1. Uluslararası Türkiye Eğitim Araştırmaları Kongresi, Türkiye.

Pradhan, N., \& Cropra, N. (2008). Communication skills for educational managers. Book Enclave.

Puncreobutr, V., \& Watttanasan, P. (2016). Structual emporwerment and organizational commitment of lecturers in private international educational institutions at Thailand. Journal of Education and Practive, 7(11), 158-163.

Purcell, J., Kinnie, N., Swart, J., Rayton, B., \& Hutchinson, S. (2009). People management and performance. Routledge.

Randall, D. M. (1987). Commitment and the organization: The organization man revisited. Academy of Management Review, 12(3), 460-471.

Robbins, S. P. (2003). Essentials of organisational behaviour. Prentice Hall.

Sağır, M. \& Parlak, F. (2018). Okul yöneticilerinin iletişim becerileri ile örgütsel güven arasındaki ilişki. Ekev Akademi Dergisi, 22(76), 165-185.

Sivik, S. (2018). Öğretmenlerin örgütsel adanmışlıkları ile lider-üye etkileşimi ve motivasyonel dil kullanımı arasındaki ilişki [Yüksek lisans tezi, Kahramanmaraş Sütçü İmam Üniversitesi]. https://tez.yok.gov.tr/UlusalTezMerkezi/ 
Spreitzer, G. M. (1995). Psychological empowerment in the workplace: Dimensions, measurement and validation. Academy of Management Journal, 3(5), 1442-1465.

Şahin, C. N. (2017). Ortaokullarda lisansüstü eğitim alan yöneticilerin örgütsel iletişim düzeyi ile ögretmenlerin karara katılma davranışlarının analizi [Yüksek lisans tezi, Maltepe Üniversitesi]. https://tez.yok.gov.tr/UlusalTezMerkezi/

Şanlı, Ö., Altun, M. \& Karaca, R. (2014). Okul yöneticilerinin iletişim becerilerinin öğretmen ve öğrenci görüşlerine göre değerlendirilmesi. İn̈nü Üniversitesi Ĕgitim Bilimleri Enstitüsü Dergisi, 1(2), 1-12.

Tabachnick, B. G., \& Fidell, L. S. (2013). Using multivariate statistics (6th ed.). Allyn and Bacon.

Taş, M. (2017). Öğretmenlerin davranışsal açıdan güçlendirilmesi ile yöneticilerin algılanan liderlik stilleri arasındaki ilişkinin incelenmesi [Yüksek lisans tezi, Maltepe Üniversitesi]. https://tez.yok.gov.tr/UlusalTezMerkezi/

Taşdan, Ş. (2007). Ortaöğretim okullarında takım çalışması (Bolu ili örneği) [Yüksek lisans tezi, Bolu Abant İzzet Baysal Üniversitesi]. https://tez.yok.gov.tr/UlusalTezMerkezi/

Tuna, B. (2003). Takım çalışmasına ilişkin yönetici ve ögretmen görüşleri [Yüksek lisans tezi, Anadolu Üniversitesi]. https://tez.yok.gov.tr/UlusalTezMerkezi/

Turgut, B. (2010). Anadolu liselerinde çalışan öğretmenlerin karar verme sürecine katılma düzeylerinin değerlendirilmesi [Yayımlanmamış yüksek lisans tezi]. Pamukkale Üniversitesi.

Tüzün, A. (2014). Algllanan örgütsel destek ve lider-üye etkileşiminin işe yabancllaşma üzerine etkisi [Yüksek lisans tezi, Haliç Üniversitesi]. https://tez.yok.gov.tr/UlusalTezMerkezi/

Ulutaş, M. (2003). Katılımcı yönetimin örgütsel bağlılık ve yaratıcılığa etkisi. Sosyal Ekonomik Araştırmalar Dergisi, 11(21), 593-615.

Ural, A. \& Kılıç, İ. (2005). Bilimsel araştırma süreci ve SPSS ile veri analizi. Detay Yayıncılık.

Uzun, O. (2011). Liderlik stilleri ile örgütsel güven ve örgütsel adanmışlık arasındaki ilişki [Yüksek lisans Tezi, Uşak Üniversitesi]. https://tez.yok.gov.tr/UlusalTezMerkezi/

Uzun, T. (2015). Okul müdürlerinin iletişim becerileri ile ögretmenlerin genel ve örgütsel sinizm tutumlarl arasındaki ilişkilerin incelenmesi [Doktora tezi, Atatürk Üniversitesi]. https://tez.yok.gov.tr/UlusalTezMerkezi/

Uzun, T. \& Ayık, A. (2016). Öğretmen görüşlerine göre okul müdürlerinin sözsüz iletişim beceri düzeylerinin belirlenmesi: Bir öncü çalışma. İletişim Kuram ve Araştırma Dergisi, 43, 150-167.

Üzüm, H. \& Kurt, T. (2019). Okullarda katılımcı karar verme sürecinin incelenmesi. Eğitim ve Toplum Araștırmaları Dergisi, 6(1), 95-112.

Wadesango, N. (2012). The influence of teacher participation in decision-making on their occupational morale. Journal of Social Sciences, 31(3), 361-369.

Whetton, D. A., \& Cameron, K. S. (2011). Developing management skills. Prentice Hall.

Yavan, Ö. (2016). Örgütsel davranış düzleminde adanmışlık. Pamukkale Üniversitesi Sosyal Bilimler Enstitüsü Dergisi, 25, 278-296.

Zhu, W., May, D. R., \& Avolio, B. J. (2004). The impact of ethical leadership behavior and employee outcomes: The roles of psychological empowerment and authenticity. Journal of Leadership \& Organizational Studies, 11(1), 16-26. https://doi.org/10.1177/107179190401100104

Zillığlu, M. (1996). İletişim nedir? Cem Yayınları.

Zöğ, H. (2007). Istanbul ili Kâğıthane ilçesinde görev yapan ilköğretim okulu öğretmenlerinin örgütsel adanmışlıkları ile iş doyumları arasındaki ilişki [Yüksek Lisans Tezi, Yıldız Teknik Üniversitesi]. https://tez.yok.gov.tr/UlusalTezMerkezi/ 


\section{EXTENDED ABSTRACT}

\section{INTRODUCTION}

The prominence of dedication in organizations is possible by increasing the importance of the human factor. When the needs and expectations of employees in an organization are met, organizational commitment increases (Güçlü, 2006). Organizational commitment which refers to the efforts of the employees to reach the goals of an organization and their loyalty to that organization (Karasoy, 2011), the high belief of the employees in the goals and values of the organization and their willingness to strive to achieve these goals by accepting them, their strong feelings to make it sustainable by staying in the organization is a desired quality (Boylu et al., 2007). The concept of empowerment of employees can be defined as a process with psychological and behavioral dimensions that increases the decision-making powers of employees and enables them to develop through cooperation, sharing, and teamwork (Koçel, 2005). This study aims to determine whether there is a significant relationship between teachers' behavioral empowerment and their organizational commitment perception levels by determining their opinions according to different variables.

\section{METHOD}

This research is descriptive and uses the survey model, which is one of the quantitative research designs. The sample consisted of 2157 teachers working in official primary, secondary and high schools in the central district of Bolu province in the first term of the 2020-2021 academic year. To collect research data, the "Teachers' Behavioral Empowerment Scale" by Kural (2015) and the "Teachers' Organizational Commitment Scale" by Celep (2000) were used. Since the data did not show normal distribution, non-parametric tests were used in the study.

\section{FINDINGS, DISCUSSION AND RESULTS}

Teachers' perceptions of behavioral empowerment in the scale's delegation of authority, managerial support, decision participation, teamwork and communication dimensions were found to be at the "most of the time" level. Delegation of authority provides teachers with the opportunity to take their development responsibilities, solve their problems, and thus gain choice, responsibility, autonomy, and authority (Araç, 2009). In this sense, the empowerment of teachers in terms of the delegation of authority is often considered a positive result. In organizations where the participatory management approach is exhibited, employees think that they are given internal rewards and thus their job satisfaction levels as well as their motivation levels increase (Chisht et al., 2010). The individual performance of the teacher, who is empowered by participating in decisions, will increase and this will lead to an increase in the educational achievement of the students and, therefore, the school.

Members' positive attitudes and behaviors towards their teammates, work, and their organizations increase their commitment to their organizations (Bülbül, 2007). It is thought that these will contribute to the organizational commitment of teachers because in a school environment where there is cooperation, respect, and support, teachers' commitment to each other will increase, their level of commitment to school and teaching will be higher, and they will show more effort in teaching. Thus, it may be stated that teamwork is very important in empowering teachers.

Teachers' communication with school administrators was reported to be at the "often" level. School administrators' empowerment of teachers in the dimension of communication is very important for the efficiency of processes such as planning, coordination, sharing, motivation, participation, cooperation, and teamwork in schools.

Teachers' perceptions of organizational commitment were at the "high" level in all dimensions. Organizational commitment also brings about positive workplace attitudes in employees. Along with organizational commitment, employees are expected to have a positive attitude toward many issues such as job satisfaction, motivation, performance, organizational commitment, and organizational citizenship behavior (Özyilmaz \& Süner, 2015). For schools to be effective and efficient and increase teachers' organizational commitment, school administrators should empower teachers, support teamwork, provide administrative support and teachers' participation in decisions, and they should establish constructive and open communication with teachers.

As teachers' perceptions of being empowered by school administrators increase, their organizational commitment levels also increase. Although there is no study in the literature in which behavioral empowerment of teachers and organizational commitment are discussed together, empowerment (Aliakbari \& Amoli, 2016; Bogler \& Somech, 2004; Chebet, 2013; İhtiyarlıŏlu, 2017; Kıral, 2015; Öznacar et al., 2016; Taş, 2017) and organizational commitment with different variables (Altunay, 2017; Döş, 2014; Ertürk, 2011; Gıc1, 2011; Kalaz, 2016; Uzun, 2011; Zhu et al., 2004) exist. 
As a result, as teachers' perceptions of being empowered by school administrators increase, their organizational commitment levels also increase. In the literature, teachers' empowerment and organizational commitment are related to different factors. Both empowerment and dedication affect different variables and are affected by different variables. For this reason, school administrators should consider the relationships and effects among these variables in school management.

\subsection{Suggestions}

\section{Implementation Recommendations}

1- It can be ensured that teachers are empowered administratively, especially, in terms of the delegation of authority and participation in decisions.

2- In raising teachers' perceptions of organizational commitment; especially,

a) in the dimension of devotion, orientation programs can be organized for teachers who have just started their profession or school, and teachers can be encouraged to participate in social activities that will contribute to school membership.

b) in the dimension of dedication to the working group, a harmonious environment can be created in the teachers' room. In addition to the activities that ensure the unity of teachers, teachers can come together on special days.

3- Behavioral empowerment of teachers can make a significant contribution in raising their perceptions of organizational commitment levels.

\section{Recommendations for Researchers}

1- Qualitative and quantitative research can be conducted to determine and compare the perceptions and expectations of teachers about behavioral empowerment and organizational commitment.

\section{ARAŞTIRMANIN ETIK IZZNI}

Yapılan bu çalışmada "Yükseköğretim Kurumları Bilimsel Araştırma ve Yayın Etiği Yönergesi" kapsamında uyulması belirtilen tüm kurallara uyulmuştur. Yönergenin ikinci bölümü olan "Bilimsel Araştırma ve Yayın Etiğine Aykırı Eylemler" başlığı altında belirtilen eylemlerden hiçbiri gerçekleştirilmemiştir.

\section{Etik kurul izin bilgileri}

Etik değerlendirmeyi yapan kurul adı: Bolu Abant İzzet Baysal Üniversitesi Sosyal Bilimlerde İnsan Araştırmaları Etik Kurulu

Etik değerlendirme kararının tarihi: 26.05.2020

Etik değerlendirme belgesi sayı ve numarası: 2020/104

\section{ARAŞTIRMACILARIN KATKI ORANI}

1. yazarın araştırmaya katkı oranı \%50, 2. yazarın araştırmaya katkı oranı \%50'dir.

Yazar 1: Araştırma konusunun belirlenmesi, araştırmanın tasarlanması, yöntemin belirlenmesi, güvenirlilik çalışmaları, verilerin toplanması, veri analizi, raporlaştırma.

Yazar 2: Araştırma konusunun belirlenmesi, araştırmanın tasarlanması, yöntemin belirlenmesi, güvenirlilik çalışmaları, verilerin toplanması, veri analizi ve raporlaştırma aşamalarında danışmanlık.

\section{ÇATIŞMA BEYANI}

Araştırmada herhangi bir kişi ya da kurum ile finansal ya da kişisel yönden bağlantı bulunmamaktadır. Araştırmada herhangi bir çıkar çatışması bulunmamaktadır. 